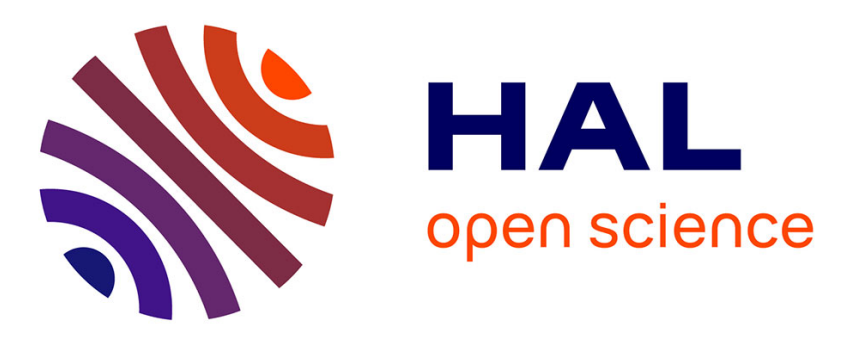

\title{
Testing provenance diagrams: Lessons from the well-constrained Cariaco Basin
}

\author{
A Riboulleau, Viviane Bout-Roumazeilles, N Tribovillard, F Guillot, P \\ Recourt
}

\section{- To cite this version:}

A Riboulleau, Viviane Bout-Roumazeilles, N Tribovillard, F Guillot, P Recourt. Testing provenance diagrams: Lessons from the well-constrained Cariaco Basin. Chemical Geology, 2014, 389, pp.91 103. 10.1016/j.chemgeo.2014.09.015 . hal-03280573

\section{HAL Id: hal-03280573 https://hal.science/hal-03280573}

Submitted on 13 Jul 2021

HAL is a multi-disciplinary open access archive for the deposit and dissemination of scientific research documents, whether they are published or not. The documents may come from teaching and research institutions in France or abroad, or from public or private research centers.
L'archive ouverte pluridisciplinaire HAL, est destinée au dépôt et à la diffusion de documents scientifiques de niveau recherche, publiés ou non, émanant des établissements d'enseignement et de recherche français ou étrangers, des laboratoires publics ou privés. 


\title{
Testing provenance diagrams: Lessons from the well-constrained Cariaco Basin
}

A. Riboulleau*, V. Bout-Roumazeilles, N. Tribovillard, F. Guillot, P. Recourt

Université Lille 1, Laboratoire Géosystèmes, UMR 8217 CNRS, bâtiment SN5, 59655 Villeneuve d'Ascq cedex, France

${ }^{*}$ Corresponding author. Tel.:+33 3204341 10; fax: +33 320434910 .

E-mail addresses: armelle.riboulleau@univ-lille1.fr (A. Riboulleau), viviane.bout@univlille1.fr (V. Bout-Roumazeilles), nicolas.tribovillard@univ-lille1.fr (N. Tribovillard), francois.guillot@univ-lille1.fr (F. Guillot), philippe.recourt@univ-lille1.fr (P. Recourt).

Keywords: Geochemistry - Provenance - Cariaco Basin - Rare earth elements - Mineral sorting

\begin{abstract}
The fine-grained sediments of the Cariaco Basin, Venezuela, of the last $130 \mathrm{ky}$, whose deposition history is well characterized, were analyzed geochemically in order to test the validity of sediment bulk geochemistry as an indicator of detrital provenance. Several binary and ternary diagrams as well as the chemical index of alteration (CIA) were tested for their capacity to discriminate the poorly contrasted detrital sources to the Cariaco Basin, and to describe the temporal evolution of the contributions of these different sources. Most of the diagrams tested did not allow a good discrimination of sources or, when sources were well discriminated, did not allow an interpretation of the temporal variations consistent with the known history. A relatively good discrimination of sources and a consistent interpretation of temporal variations were however obtained using $\mathrm{Hf}$ vs. Th and $\mathrm{La} / \mathrm{Yb}$ vs. $\mathrm{Gd} / \mathrm{Yb}$ binary diagrams, as well as $\mathrm{Ti}-\mathrm{Zr}-\mathrm{Th}, \mathrm{Ti}-\mathrm{Zr}-\mathrm{La}$, and $\mathrm{Lu}-\mathrm{Hf}-\mathrm{Th}$ ternary diagrams. Compared to the previous studies of the detrital content of the Cariaco Basin sediments, the geochemical approach permitted the recognition of a sediment contribution eroded from the Unare platform and Gulf of Cariaco during rapid sea level oscillations, and the contribution of Saharan eolian particles during the Younger Dryas-Preboreal and MIS6-5 transition. The choice of plotted elements was determined after considering carrier minerals, so that different
\end{abstract}


elements may be informative in different sedimentary contexts. Overall, mineral sorting during transport appears as a major limit to quantitative estimation of the different contributions. In particular mineral sorting leads to the selective enrichment of elements associated with clays (Al, Rb, Th and LREE) in sediments deposited in the basin. Unless the geochemical effect of mineral sorting can be measured, it appears that quantitative provenance analysis should be performed on fractions of similar grain size instead of bulk sediment.

\section{Introduction}

Provenance analysis has historically been based on mineralogical studies of sandstones (see Weltje and von Eynatten, 2004 for a review), however the analysis of whole-rock element composition has known an increasing interest during the last decades, as it is a convenient method that can be applied on any type of sediment and (meta-)sedimentary rock (e.g., Bhatia and Crook, 1986; McLennan, 1989; McLennan et al., 1993; Mongelli et al., 1996; Young, 1999; Cullers, 2002; Mahlen et al., 2005; Pe-Piper et al., 2008; Spalletti et al., 2008). The range of information obtained by this geochemical approach is wide, but in particular, provenance analysis is largely applied on sedimentary rocks in order to determine their paleotectonic and/or paleogeographic settings (Eriksson et al., 1992; Garver et al., 1996; Savoy et al., 2000; Joo et al., 2005; Meinhold et al., 2007; Spalletti et al., 2008). Another application of geochemical provenance analysis for both ancient and recent deposits is the determination of paleoclimatic conditions and their variability, through the use of weathering indices such as the chemical index of alteration (CIA; Nesbitt and Young, 1982, 1984) or by the identification of the geographic origin of the detrital flux, allowing to determine changes in rainfall patterns or marine currents (Young, 1999; Young and Nesbitt, 1999; Yarincik et al., 2000; Passchier, 2004; Latimer et al., 2006; Martinez et al., 2010; Monien et al., 2012).

In order to identify the tectonic setting of sediments, different discrimination diagrams have been proposed (Nesbitt and Young, 1984; Bhatia and Crook, 1986; Roser and Korsch, 1986; McLennan et al., 1993). These diagrams have been developed for sandstones and several studies demonstrated that discrimination diagrams were sometimes inefficient for the accurate identification of paleotectonic settings (Totten et al., 2000; Armstrong-Altrin and Verma, 2005; Ryan and Williams, 2007; Pe-Piper et al., 2008). Mineralogical sorting during sand deposition is one of the reasons for this failure (Garcia et al., 2004; Ohta, 2004). Despite this, discrimination diagrams are still often used, and in particular those based on trace metals have been extended to fine-grained and/or carbonate sediments (e.g., Mongelli et al., 1996; 
Cullers, 2002; Pe-Piper et al., 2008). In the case of fine-grained sediments, multi-element diagrams may be used in order to compare the chemical characteristics of a sediment and its possible sources of known composition, an approach particularly useful in Quaternary paleoclimatology (Yang et al., 2003; Latimer et al., 2006; Montero-Serrano et al., 2010; Monien et al., 2012). Difficulties however may arise if the considered sources present similar geochemical characteristics (Pe-Piper et al., 2008).

In the present study, we assessed the effectiveness of the geochemical approach in discriminating and identifying detrital sources showing poorly contrasting geochemical characteristics. For this purpose, we used the recent sediments from the Cariaco Basin, Venezuela. The Cariaco Basin is the second largest euxinic basin in the world and its annually laminated organic-rich sediments represent one of the best low-latitude paleoclimatic records (Peterson et al., 1991, 2000; Hughen et al., 1996, 2004b; Black et al., 2009; Goni et al., 2009; among others). For these reasons, the water column and sediments of the Cariaco Basin have been the object of numerous oceanographic, geochemical, biological and paleoclimatic studies (e.g., Tuttle and Jannasch, 1979; Scranton, 1988; Wakeham and Ertel, 1988; Peterson et al., 1991; Haug et al., 2001;Muller-Karger et al., 2004; among others). The present-day pattern of detrital sedimentation in the Cariaco Basin has recently been the object of provenance studies based on the geochemistry and clay mineralogy of surface sediment (Martinez et al., 2007, 2010; Elmore et al., 2009; Bout-Roumazeilles et al., 2013). The geochemical study of Martinez et al. (2010) however revealed that the different detrital sources to the Cariaco Basin presented relatively similar geochemical features. Past variations of the detrital input to the Cariaco Basin also have been explored on several timescales, in particular by the use of the clay mineral content (Clayton et al., 1999; Black et al., 2009; Bout-Roumazeilles et al., 2013; Riboulleau et al., 2014), so that the detrital history of the Cariaco Basin during the last glacial cycle is relatively well known. Temporal variations of the sediment geochemistry compared to the clay mineralogical proxies therefore offer the opportunity to test geochemical provenance tools in this restricted and well-constrained context.

\section{Material and methods}

\subsection{Studied material}

The present study is based on sediment from the IMAGES Program core MD03-2625 $\left(10^{\circ} 40.65^{\prime} \mathrm{N}, 64^{\circ} 58.24^{\prime} \mathrm{W}\right.$, water depth $\left.847 \mathrm{~m}\right)$ recovered during the PICASSO cruise (R/V Marion Dufresne; Laj and Shipboard Scientific Party, 2004) and Ocean Drilling Program 
(ODP) Site $1002\left(10^{\circ} 42.36^{\prime}\right.$ N, 65¹0.16’ W; water depth, 893 m; Shipboard Scientific Party, 1997). Sediments from Holes 1002D and E were used in order to get the most complete record (Hughen et al., 2004a). Both coring sites are located on the central saddle of the Cariaco Basin, however core MD03-2625 is located on its eastern side while ODP site 1002 is located on its western side (Fig. 1).

Geochemical data from the platform surrounding the Cariaco Basin (Martinez et al., 2010), from sediment cores PL07-39PC (Piper and Dean, 2002) and ODP 1002 (Yarincik et al., 2000) and from sediment traps (Martinez et al., 2007; Martinez, 2009) are added to the discussion. Location of these different samplings is presented in Fig. 1.

\subsection{Age model}

For Site ODP 1002, as previously observed by Hughen et al. (2004a), the ODP depth scale does not allow a perfect correlation of the different ODP 1002 holes. A new composite depth scale was therefore established by correlating the parameter $\mathrm{L}^{*}$ and the magnetic susceptibility of cores 1002C, 1002D and 1002E (Riboulleau et al., 2014; Table S1, Fig. S1). The age model was then derived from the age models established by Hughen et al. (2006) and Drenzek (2007) using the new composite depth scale. In brief, for sediment younger than 75 ka (Hughen et al., 2006), the age model is based on the correlation of core 1002D sediment reflectance with 230Th-dated stalagmite $\delta 180$ records from Hulu Cave, China (Wang et al., 2001). For sediment older than $75 \mathrm{ka}$, the age model is based on a correlation of the oxygen isotopic composition of planktonic foraminifer Globigerinoides ruber shells collected from core 1002D (Drenzek, 2007),with the global benthic foraminiferal $\delta 18$ Ostack of Lisiecki and Raymo (2005).

For core MD03-2625 (Table S2, Fig. S2), the age model was determined by correlating the colorimetric parameter $\mathrm{a}^{*}$, describing sediment color from red to green, acquired on board (Laj and Shipboard Scientific Party, 2004) with gray-scale data of core PL07-56PC (Hughen et al., 1996), using a more recent age model (Hughen et al., 2000). For the correlation, core PL07-56PC was preferred over core ODP 1002, because it is located closer to core MD03-2625 and is very well dated (Hughen et al., 1996, 1998, 2000). The software used for the correlation was AnalySeries (Paillard et al., 1996). The obtained ages are calibrated years before present (a cal. B.P.).

\subsection{Methods}


A total set of 190 samples was analyzed, covering the entire climatic cycle. Samples originate from core MD03-2625 for the interval 0-11.66 ka, and from ODP 1002D and E for the interval 11.60-132.55 ka (Table S3). Continuity of the record was ascertained by the colorimetric correlation of the different cores. The sampling step varied according to the considered period: 10 to $20 \mathrm{~cm}$ for interglacials (Holocene to Bølling-Allerød; MIS5e to MIS6) and Dansgaard/Oeschger cycle 8; 10 to $130 \mathrm{~cm}$ (average $44 \mathrm{~cm}$ ) for the glacial period sensu lato (MIS2 to MIS5d),with a minimum of two samples per stadial and per interstadial for MIS3.

Bulk sediment geochemical analyses were performed at the Service d'Analyse des Roches et des Minéraux, a facility of the Centre National de la Recherche Scientifique (Vandoeuvre-les-Nancy, France). Elements were analyzed after fusion with LiBO2 and HNO3 dissolution, using an ICP-OES IRIS Advantage ERS - ThermoFisher (major and minor elements) and an ICP-MS X7 - ThermoFisher (trace and rare earth elements), without pre-concentration of REE and U/Th (Carignan et al., 2001). Standards BR, AN-G, UB-N, DR-N, and GH were used for calibration. Precision and accuracy were found to be better than $5 \%$ for most major, minor, trace and rare earth elements, and $10 \%$ for Co, Cs, $\mathrm{Hf}, \mathrm{Sn}$, Th and $\mathrm{W}$, as checked by replicate analysis of standards (Carignan et al., 2001). The carbonate content was determined using a Bernard Calcimeter (via acid digestion). The relative error is about 2\%. Detailed geochemical data and analytical uncertainty are given in Table S3.

The $\mathrm{A}-\mathrm{CN}-\mathrm{K}$ diagram and CIA are calculated using molar proportions of $\mathrm{A}: \mathrm{A} 12 \mathrm{O} 3$, $\mathrm{CN}: \mathrm{CaO}^{*}+\mathrm{Na} 2 \mathrm{O} ; \mathrm{K}: \mathrm{K} 2 \mathrm{O}$ and $\mathrm{CIA}=\mathrm{A} /(\mathrm{A}+\mathrm{CN}+\mathrm{K}) \times 100 \cdot \mathrm{CaO} *$ designates calcium oxide which is only present in silicate phases and is calculated by subtracting the $\mathrm{CaO}$ associated with carbonates and phosphate to the total $\mathrm{CaO}$ content (Fedo et al., 1995). Unless stated, all presented plots are based on raw geochemical data.

As samples analyzed for geochemistry had been totally ground, heavy minerals were identified in two samples neighboring the two Zr-richest samples (see Table S3): 1002D 2H2 73-75, located just above AR 74 (1002D 2H2 75-77) and 1002E 6H5 12-14,which is almost equivalent to AR 190 (1002D 6H2 125-127). Approximately $10 \mathrm{~g}$ of sediment was sieved with deionized water on a $40 \mu \mathrm{m}$ sieve. The fraction $\mathrm{N} 40 \mu \mathrm{m}$ weighed $1.2 \mathrm{~g}$ for each sample. This fraction was decanted on sodium polytungstate (density 2.85 ). The $\mathrm{d} N 2.85$ fraction was washed with deionized water, dried at $40{ }^{\circ} \mathrm{C}$ and coated with carbon. The minerals were identified by observation with a FEI Quanta 200 environmental scanning electron microscope (ESEM) and analysis with a Bruker XFlash 3001 energy dispersive spectroscopy (EDS) probe 
device. Heavy minerals were also researched in the $<40 \mu \mathrm{m}$ fraction by observation and analysis with the same material after drying and coating with carbon.

\section{Background}

The Cariaco Basin is a small depression located in the northern margin of Venezuela. It is subdivided into two sub-basins ca. $1400 \mathrm{~m}$ deep each. The sedimentation in the Cariaco Basin results both from an autochthonous production dominated by diatoms and coccoliths, and a detrital sedimentation delivered by the different rivers surrounding the basin (Fig. 1). Both in water column and on sea floor, the sediment is dominated by the detrital part (Peterson et al., 2000; Haug et al., 2001; Piper and Dean, 2002; Thunell et al., 2007).

Two decades ago, the first mineralogical and geochemical provenance studies of the Cariaco Basin identified three main detrital sources: "local rivers", the Orinoco-Amazon plume and eolian particles of Saharan origin. The respective contributions from these different sources fluctuated at the glacial-interglacial timescale (Clayton et al., 1999; Yarincik et al., 2000). More recently, based on clay mineralogy and geochemical data, it was proposed that the sedimentation collected in the sediment trap located in the eastern subbasin, resulted from the mixing of a dominant fraction of sediment from local rivers, in particular the Unare River, with an unidentified "upper crust" component and a minor eolian contribution of Saharan origin (Martinez et al., 2007, 2010; Elmore et al., 2009). BoutRoumazeilles et al. (2013), using the clay mineral content of the sediment and the temporal data from Clayton et al. (1999), evidenced that the Tuy and Unare rivers were the main contributors to the sedimentation at ODP site 1002. They could not identify any eolian contribution. All these recent studies definitely excluded the Orinoco/Amazon plume as a significant source of sediment to the Cariaco Basin (Martinez et al., 2007, 2010; Elmore et al., 2009; Bout-Roumazeilles et al., 2013).

Temporal studies mainly based on ODP core 1002 showed that during the Quaternary, climatic and eustatic fluctuations modified qualitatively and quantitatively the detrital flux delivered to the Cariaco Basin (Clayton et al., 1999; Peterson et al., 2000; Yarincik et al., 2000; Haug et al., 2001; Peterson and Haug, 2006). Qualitative variations mostly consist of a change of the dominant detrital sources: if the Unare River appears largely dominant during glacial periods, the contribution from the Tuy and Neveri (+Manzanares) rivers increases during interglacials (Bout-Roumazeilles et al., 2013; Riboulleau et al., 2014). Northward shift of the rain belt during the interstadials of the Dansgaard-Oeschger oscillations lead to increased detrital flux (Peterson and Haug, 2006). No significant changes in the clay 
mineralogy during Dansgaard-Oeschger oscillations are observed, however, rapid sea level fluctuations are characterized by remobilization of the sediment from the Unare Platform (Riboulleau et al., 2014). An eolian contribution is only noted in the sediments deposited during the Younger Dryas (YD) and at the MIS6-5 transition (Riboulleau et al., 2014).

\section{Results}

\subsection{Major and minor elements}

A good correlation is observed between $\mathrm{Al}, \mathrm{K}, \mathrm{Fe}$ and Ti (Table 1, Table S4), indicating that these elements clearly have a detrital origin. A poor to negative correlation is observed between these elements and $\mathrm{Na}, \mathrm{Ca}$ and $\mathrm{Mg}$, pointing that the latter elements are mostly related to biogenic and/or authigenic enrichment. Si and Al are poorly correlated (Table 1), but when presented on a Si vs. Al diagram (Fig. 2), it appears that Si and Al are generally correlated, but the correlation is blurred for a subset of samples. These outliers are as follows: samples between 14.6 and $10 \mathrm{ka}$, a few samples in MIS 2 and 3, one sample from the beginning of MIS5e and the samples from MIS 6. Smear slide observations of these sediment samples reveals that these outliers contain diatom frustules and/or abundant quartz grains compared to the other samples. Overall the Si content mostly has a detrital origin, though in some samples (transitions MIS 6-5e and MIS 2-1) a biogenic contribution is also present.

Temporal variations of the aluminum-normalized contents of the detrital elements generally show a similar long-term trend that is correlated to the global seawater $\delta 180$ (Figs. 3, S3, Table 2). Low $\mathrm{Si} / \mathrm{Al}, \mathrm{Fe} / \mathrm{Al}$ and $\mathrm{Ti} / \mathrm{Al}$ and high $\mathrm{K} / \mathrm{Al}$ values characterize interglacials while high $\mathrm{Si} / \mathrm{Al}, \mathrm{Fe} / \mathrm{Al}$ and $\mathrm{Ti} / \mathrm{Al}$ and low $\mathrm{K} / \mathrm{Al}$ values characterize glacials. Superimposed on this general trend, several peaks are observed in the $\mathrm{Si} / \mathrm{Al}$ and/or Ti/Al ratios, in particular during the YD and MIS6 (Fig. 3, arrows). Several individual samples in MIS 2, 3 and 5 also show high values of metal/aluminum (Me/Al) ratios, in particular a sample at $16.8 \mathrm{ka}$ (Fig. 3). Though the enrichment may also concern other elements, for convenience, these samples are termed as "Ti-rich" in the following. Systematic variations of Me/Al ratios associated with stadials, interstadials, or Heinrich events are not observed (Fig. 3).

\subsection{Trace and rare earth elements}

Elements commonly used in order to determine detrital source origin (provenance) and considered as geochemically "immobile" elements include REE, Th, Co, Cr, Hf, and Zr. In the sediments of the Cariaco Basin, most of these elements are strongly correlated with $\mathrm{Al}$ 
(Table S4), confirming their detrital origin. Only $\mathrm{Cr}$ and $\mathrm{Co}$, which also can be influenced by redox conditions (Tribovillard et al., 2006), show moderate correlation with Al (Table S4).

When normalized to Al, only Co and to a lesser extent $\mathrm{Cr}$ variations are dominated by the long-term correlation with the global seawater $\delta 180$ observed for major elements (not shown). For the other elements (Fig. S3), this long-term trend is either absent (Th, LREE), or is present but stronger variations are superimposed ( $\mathrm{Hf}, \mathrm{Zr}, \mathrm{Y}, \mathrm{HREE}$ ). High values of metal (Me) ratios are observed in the Ti-rich samples defined above: 1) the sample at $16.8 \mathrm{ka} ; 2$ ) YD and MIS6; 3) small peaks during MIS5 and MIS3 (Fig. 3, arrows). The same long-term trend and/or small peaks are present in the temporal variations of some element ratios $(\mathrm{Zr} / \mathrm{Ti}$, $\mathrm{La} / \mathrm{Lu}, \mathrm{Gd} / \mathrm{Yb}$; Fig. 3). Small peaks within MIS5 are however not visible in the REE ratios (Fig. 3). Again, systematic variations of Me/Al ratios associated with stadials, interstadials, or Heinrich events are not observed.

\subsection{Heavy minerals}

Heavy mineral identified in the N40 $\mu \mathrm{m}$ fraction of the two studied samples mostly consist of epidote, zircon, rutile, mica, titanite, garnet, and an Al-silicate likely corresponding to kyanite (Figs. S4, S5). Grains are generally b100 $\mu \mathrm{m}$ in diameter and are well rounded to subangular (Figs. S4, S5). The relative abundance of minerals differs among samples: epidote is abundant in sample 1002D 2H2 73-75 while zircon and mica are abundant in sample 1002E 6H5 12-14. In addition, abundant K-micas (muscovite and phengite) were observed in sample 1002E 6H5 12-14.

The $<40 \mu \mathrm{m}$ fraction is dominated by aggregates of clay minerals (Figs. S6, S7). In this fraction, heavy minerals detectable by SEM using backscattered electrons mostly consist of pyrite grains. Nonetheless, small zircons, rutile and phosphates (monazite and xenotime), were identified in the two samples (Figs. S6, S7).

\section{Discussion}

\subsection{Mineralogical control on the detrital signal}

The cross correlation of elements (Tables S4 and S5) added to the observation of sediment smear slides and identification of heavy minerals (Section 4.3), allows identifying the principal minerals carrying the geochemical signal (McLennan, 1989, 1993). This identification allows understanding the behavior of elements in provenance diagrams, but also allows selecting the most relevant elements to plot for provenance analysis. 
From smear slide observations, Si rich intervals in Cariaco sediments are related to the presence of diatomaceous opal, and/or to abundant quartz grains. When quartz-rich and opalrich samples are excluded (Table S5), $\mathrm{Si}$ is best correlated with $\mathrm{Ti}(\mathrm{r}=0.976)$, followed by HREE and $\mathrm{Hf}(\mathrm{r}=0.942$ to 0.960$)$. The correlation of $\mathrm{Si}$ with $\mathrm{Al}$ is poorer $(\mathrm{r}=0.904)$. $\mathrm{Ti}$, HREE and Hf are generally associated with heavy minerals (McLennan, 1989; McLennan et al., 1993), while Al is rather associated with clay minerals. From the correlations of Si with Ti, REE and Hf, it appears that, biogenic opal excepted, the Si content reflects quartz grains that deposit in association with heavy minerals.

Potassium is best correlated with $\mathrm{Al}, \mathrm{Cs}, \mathrm{Pb}, \mathrm{Rb}$, Th and $\mathrm{La}-\mathrm{Pr}(\mathrm{r} \geq 0.970)$ while no correlation is observed with $\mathrm{Ba}(\mathrm{r}=0.422$; Table S4). From the poor correlation with $\mathrm{Ba}$, an element enriched in K-feldspar, and the good correlation with $\mathrm{Cs}$ and $\mathrm{Rb}$, elements enriched in muscovites (e.g., Alfonso et al., 2003), the K content in Cariaco sediments appears mostly controlled by K-micas and illite clay minerals, rather than by $\mathrm{K}$-feldspars. This conclusion is supported by the abundance of K-micas in sample 1002E $6 \mathrm{H} 5$ 12-14, and by the parallels between temporal variations of the illite content (Riboulleau et al., 2014) and the K/Al ratio of the sediment.

$\mathrm{Fe}$ is best correlated with $\mathrm{Ti}(\mathrm{r}=0.958$, Table $\mathrm{S} 4)$. This suggests that Fe variations are related to $\mathrm{Ti}$ - and Fe-containing minerals such as ilmenite, titanomagnetite or rutile. A few Fe-containing titaniferous minerals were identified in the heavy mineral fraction; however most Ti-mineral identified are Fe-poor (Figs. S4-S7). Other Fe-bearing heavy minerals identified are garnet, and an Al-silicate likely corresponding to kyanite, in addition to small pyrite (Figs. S4, S5). The correlation between Fe and Ti could result from the hydrodynamic association of Ti-bearing and Fe-bearing heavy minerals.

Ti is best correlated with $\mathrm{Si}, \mathrm{Al}, \mathrm{Fe}, \mathrm{MREE}$ and HREE, Cs and Pb (Tables S4 and S5). Titaniferous minerals identified in the coarse and fine fractions of the Cariaco sediment mainly correspond to rutile and titanite (Section 4.3). While titanite is enriched in MREE and HREE (Green and Pearson, 1983; Klemme et al., 2005), rutile is poorly enriched in REE (Tribuzio et al., 1996).Most titaniferous heavy minerals also include $\mathrm{Nb}$ and/or Ta as trace metals (Schock, 1979; Green and Pearson, 1983; Klemme et al., 2005). The absence of very good correlation between $\mathrm{Ti}$ and $\mathrm{Nb}$ or $\mathrm{Ta}$ (Table S4) suggests that Ti-rich heavy minerals are not the only minerals controlling Ti in Cariaco sediments. The good correlation of Ti with Al and Cs suggests a control of Ti by clay minerals. Accordingly, EDX analysis of clay aggregates indicates that the Cariaco clays are Ti-rich, with $\mathrm{TiO} 2$ contents around 1 wt.\% (Fig. S8). 
The only element well correlated with $\mathrm{Zr}$ is Hf (Table S4), consistent with the high abundance of this latter element in zircon (Fujimaki, 1986). Zircon has been observed in both the coarse and fine fractions of the studied samples (Section 4.3) and is one of the most abundant heavy minerals in the sediments of the platform surrounding the Cariaco Basin (De Miró Orell, 1974).

Thorium is well correlated to several elements ( $\mathrm{Al}, \mathrm{K}, \mathrm{CS}, \mathrm{Nb}, \mathrm{Pb}, \mathrm{Rb}, \mathrm{Ta})$, however the highest correlation coefficients ( $\mathrm{r} \mathrm{N} \mathrm{0.99)}$ ) are observed with $\mathrm{La}, \mathrm{Ce}$ and $\mathrm{Pr}$ (Table S4). This suggests that thorium is controlled by heavy minerals rich in LREE such as monazite (Hutton, 1950; Franz et al., 1996) or allanite-like epidotes (Gieré and Sorensen, 2004). While no monazite grain was observed among the coarse heavy minerals, one small monazite grain, $10 \mu \mathrm{m}$ in diameter, was identified in the fine fraction of the studied samples (Fig. S6). Numerous epidotes were observed in one of the studied samples, however these epidotes are poor in LREE and likely do not correspond to allanite (Fig. S4). From the good correlation with $\mathrm{Al}, \mathrm{Cs}$ and $\mathrm{Rb}$, thorium could be controlled either by clay minerals, or by small monazite grains that deposited in association with clays. Likewise, niobium may be controlled by clay minerals or by fine-grained heavy minerals.

Heavy and light REE do not show the highest correlations with the same elements (Table S4): LREE are best correlated with Th and to a lesser extent with $\mathrm{Nb}, \mathrm{Pb}, \mathrm{Rb}, \mathrm{Cs}$, Ta, $\mathrm{Al}$, and $\mathrm{K}$, suggesting that, similarly to Th, LREE are controlled by clays or by very finegrained heavy minerals, associated with clays. HREE (and MREE) only show good correlation with Ti and Y (Table S4), suggesting that HREE are controlled by titanite (Green and Pearson, 1983; Klemme et al., 2005) and xenotime (Franz et al., 1996). Both minerals were observed in the studied sediments (Section 4.3). Though zircon is often enriched in HREE (Fujimaki, 1986), only a poor correlation is here observed between $\mathrm{Zr}$ and HREE (Table S4). When quartz-rich and opal-rich samples are excluded, HREE also show a good correlation with Si (Table S5). This could reflect an additional control by garnet as this mineral, often enriched in HREE (Schwandt et al., 1996), was observed in the heavy mineral fraction of the studied sediments (Section 4.3).

\subsection{Provenance analysis}

\subsubsection{A-CN-K and MFW ternary diagrams}

In the $\mathrm{A} 12 \mathrm{O} 3-(\mathrm{CaO} *+\mathrm{Na} 2 \mathrm{O})-\mathrm{K} 2 \mathrm{O}(\mathrm{A}-\mathrm{CN}-\mathrm{K})$ diagram, the data from the cores, platform and sediment trap generally overlap along a line almost parallel to the A-CN axis (Fig. 4). This overlapping of data on a single line, that overall corresponds to the trend 
obtained by weathering of an intermediate rock (Nesbitt and Young, 1984), suggests that all sediments from the platform, cores and sediment traps in the Cariaco Basin originate from a similar magmatic source. The degree of weathering expressed by the CIA (Nesbitt and Young, 1982) varies between 33 and 78 for the cores and shows moderate temporal variations (Fig. 4C). The lowest CIA value is observed in the most recent part of the studied section (0$14.6 \mathrm{ka}$; average 53) while relatively similar values (average 64 to 69) are observed in the rest of the section (Fig. 4C; Table 3). Grain size variations on the studied interval are moderate and the sediment is dominated by fine silts (Table 4). The sediment in the 0-14.6 ka interval shows a higher proportion of sands than older sediment (Table 4), which might explain the lower CIA values in this interval. CIA values from the platform (Martinez et al., 2010) and sediment traps (Martinez, 2009) are comparable to the values of cores (Fig. 4, Table 3). On the platform, the highest average CIA values are observed for the Unare, Neveri and Manzanares rivers while low values characterize the Araya-Margarita-Tortuga areas (Fig. 4B). These features are consistent with local geology (Hackley et al., 2006) and climate conditions: the drainage basin of the Unare, Neveri and Manzanares rivers mainly consists of sedimentary rocks and the dominantly metamorphic rocks of the Araya-Margarita area are principally altered by physical weathering due to arid conditions (Goldbrunner, 1984). The mean grain size of the sediment also influences CIA values: the sediment from the ArayaMargarita-Tortuga areas has the highest proportion of sand (De Miró Orell, 1974) and the lowest CIA values, while sediments deposited at the mouth of the Tuy, Unare and Neveri rivers are dominated by clays and silts (De Miró Orell, 1974; Martinez et al., 2010) and show high CIA values (Table 3). The CIA value of the Unare North area is lower than CIA value of the rest of the Unare platform (Table 3), consistent with the higher sand content in this part of the platform (De Miró Orell, 1974). From the direct interpretation of CIA values and location of sources in the $\mathrm{A}-\mathrm{CN}-\mathrm{K}$ diagram, no clear discrimination of detrital sources is possible. Moreover, direct interpretation of the temporal variations in the cores suggests that sediments deposited during the $0-14.6 \mathrm{ka}$ interval had a strong influence from the Tortuga- Margarita area that is not supported by the clay mineral content (Bout-Roumazeilles et al., 2013; Riboulleau et al., 2014). Suspended sediments from different rivers (McLennan, 1993) are also plotted for comparison. While sediments from the Mississippi, Huanghe and Congo rivers do not plot close to the Cariaco data, suspended particles from the Amazon, Orinoco and Nile rivers do (Fig. 4A). Direct interpretation of the plot therefore might suggest that these three rivers contribute to the sedimentation in the Cariaco Basin. While the Nile River 
obviously does not contribute to the sedimentation in the Cariaco Basin, a contribution from the Amazon and Orinoco rivers has been suspected (Clayton et al., 1999; Yarincik et al., 2000). Several more recent studies however document that neither the Amazon nor Orinoco rivers contribute to the sedimentation in the Cariaco Basin (Martinez et al., 2007, 2010; Elmore et al., 2009; Bout-Roumazeilles et al., 2013). The comparison of Cariaco data with modern rivers exemplifies the poor specificity CIA values and of the $\mathrm{A}-\mathrm{CN}-\mathrm{K}$ diagram and therefore demonstrates their uselessness for provenance analysis.

We also tested the mafic-felsic-weathering (MFW) ternary diagram developed by Ohta and Arai (2007) which is intended to be more precise than the A-CN-K diagram (Fig. 5). The platform samples (Martinez et al., 2010) are poorly discriminated and overlap in the central part of the MFW diagram. Compared to the core sediments, the platform data are generally located closer to the W pole (Fig. 5). According to Ohta and Arai (2007), this indicates that the platform sediment is more weathered than the sediment deposited in the middle of the basin. The location of core samples in the MFW diagram suggests that the sediment mainly derives from the weathering of intermediate to mafic igneous rocks (Fig. 5), a conclusion partly consistent with the $\mathrm{A}-\mathrm{CN}-\mathrm{K}$ diagram. The samples from the most recent part of the section however distinguish from the rest of the series and are shifted towards intermediate rocks. This shift of the 0-16.4 ka samples in the MFW diagram partly results from the presence of biogenic opal in the sediment, leading to increased $\mathrm{SiO} 2$ content (Table S3). A slightly different origin of the detrital sediments of this age is however also indicated by clay minerals (Riboulleau et al., 2014). From the MFW diagram the platform sediments would derive from intermediate to felsic igneous rocks, which would therefore be different from the source of the sediment in the central part of the basin. Overall, the conclusions reached with the MFW diagram are not consistent with the known history and origin of the detrital sources of the Cariaco Basin. The poor efficiency of the MFW diagram here observed may result from several factors: the first one is sediment sorting. The MFW diagram was developed from weathering profiles of magmatic rocks, and not from sediments deposited by erosion of these rocks (Ohta and Arai, 2007). Therefore in the original database, the Si and Al contents resulted from magmatic differentiation and weathering alone. In the case of deposited sediments, Si and Al contents are also affected by grain sorting during transport. As expected, the sediments from the platform surrounding the Cariaco Basin present generally higher Si/Al ratios than the sediments in the core (Fig. S9A). Consistent, the sediments with the highest proportion of sand (Unare North, Araya-Margarita, Tortuga-Margarita, Manzanares for the platform and 0-14.6 ka for the core) are generally shifted towards the 
felsic pole compared to the other samples (Fig. 5). The $\mathrm{Mg} / \mathrm{Al}$ ratio is conversely higher in core sediments than in platform sediments (Fig. S9B). This feature could result from the authigenesis of $\mathrm{Mg}$ smectites in relation to the dissolution of diatom frustules in the sediments (Michalopoulos et al., 2000). Indeed, diatoms are important contributors to the sedimentation in the Cariaco basin during the upwelling season (Ferraz-Reyes, 1983), and opal represents a significant fraction of the flux collected in the sediment traps (Thunell et al., 2007). Biomarker analyses indicate that diatoms were also present in the basin during the last glacial period (Quijada, 2012). Despite this, opal is absent from most of the studied interval and only detected in the sediments of MIS5e and in the interval 14.6-10 ka, confirming that important opal dissolution occurred in the sediment. The poor correlation observed between the $\mathrm{Al}$ and Mg contents in the core sediments (Table 1, Fig. S9B) while platform sediments generally show a good correlation between $\mathrm{Mg}$ and $\mathrm{Al}$ (Fig. S9B) also supports authigenic $\mathrm{Mg}$ enrichment in the core samples. As a result of their higher Si content and lower Mg content, the platform sediments are shifted towards the F pole compared to core samples (Fig. 5). The present data on the well-constrained Quaternary sediments on the Cariaco Basin therefore give support to the conclusion reached by the study of Cretaceous rocks (Pe-Piper et al., 2008) that the MFW diagram is not pertinent for provenance analysis.

\subsubsection{Me vs. Al plots - Me/Al ratios}

In Me (metal) vs. Al plots, discrimination of the possible sediment sources will be possible if the sources present contrasting values of the Me/Al ratio. In most plots of Me vs. Al except Ti vs. Al, the Tuy River is distinguished by its low Me/Al ratios and the Manzanares River by its high Me/Al ratios, the Unare and Neveri data however cannot be distinguished as they present a similar range of Me/Al ratios (Fig. S10). Only in the Hf vs. Al plot the Neveri, Unare North and Unare South areas are somewhat separated (Fig. S10). The comparison of the sandy sediments of the Unare North area with the silty clays of the Unare South area allows estimating the influence of variable sediment grain size on the distribution in the Me vs. Al plots. Sediments of Unare North present higher $\mathrm{Zr} / \mathrm{Al}$ and Hf/Al ratios than sediments of Unare South, but similar K/Al, Ti/Al, La/Al (Fig. S10) and Th/Al (not shown) ratios. This indicates that $\mathrm{Zr}$ and $\mathrm{Hf}$ are associated with the coarser fractions, while $\mathrm{K}$, Ti, $\mathrm{La}$ and Th are mostly associated with clays, consistent with the conclusions reached by element correlation (Section 5.1). When temporal data are presented in Me/Al plots, temporal changes of the detrital source(s) can be indicated by a change in the slope of the correlation between the metal and Al. As previously discussed, temporal changes in sediment grain size may 
influence the distribution of samples in the Zr vs. Al and Hf vs. Al plots. The "coarse" sediments from the $0-14.6 \mathrm{ka}$ interval however have similar $\mathrm{Zr} / \mathrm{Al}$ and $\mathrm{Hf} / \mathrm{Al}$ ratio than the other core samples (Fig. 6), suggesting that the modest changes in the sediment grain size (Table 4) have minor influence. Comparing the core data with the different areas from the platform in Me vs. Al cross plots (Fig. 6) indicates a stronger influence of the Tuy River during the 0-14.6 ka interval and MIS5, and of the Unare+ Neveri during glacials. This interpretation is overall consistent with the conclusions reached with clay minerals (BoutRoumazeilles et al., 2013; Riboulleau et al., 2014) but lacks detail. A direct interpretation of most Me vs. Al cross plots (Ti, Zr, Hf and Lu; Fig. 6) also indicates that the contribution from the Manzanares River, if present, is more important during glacials, which is inconsistent with the conclusions reached with clay minerals (Bout-Roumazeilles et al., 2013; Riboulleau et al., 2014). The Ti-rich samples often diverge from the general Me vs. Al correlation drawn by the core samples, in particular in the $\mathrm{Zr}$ vs. Al, Hf vs. Al and Lu vs. Al diagrams (Fig. 6). From their location in the cross plots, these samples could present a strong contribution from the Manzanares and/or Unare North area.

The $\mathrm{Ti} / \mathrm{Al}$ (or $\mathrm{Al} / \mathrm{Ti}$ ) ratio is often used as a marker of detrital source, and has been used in particular by Yarincik et al. (2000) and Martinez et al. (2007, 2010) in order to compute the contribution of the different detrital sources to the sedimentation of the Cariaco Basin. Direct comparison of the different Ti/Al values obtained from the Cariaco Basin (Fig. S11) shows that average values in the sediment traps (Martinez et al., 2007) and in Holocene sediments from cores (this study, Yarincik et al., 2000; Piper and Dean, 2002), are systematically lower than average values on the platform (Martinez et al., 2010). Indeed, for most elements associated with heavy minerals ( $\mathrm{Ti}, \mathrm{Zr}$, Hf, $\mathrm{Lu}$ ), cores and sediment traps have lower average $\mathrm{Me} / \mathrm{Al}$ ratios than platform sediment (Fig. S10). This indicates that sediments from the basin are enriched in clays compared to the platform, consistent with the generally observed differential settling of grains during transport and sedimentation. Martinez et al. (2010) used platform Ti/Al ratios in order to model the sediment trap Ti/Al values. In their calculation, a source carrying an "upper crust" signature was needed, despite the lack of identification of a detrital source carrying this "upper crust" signature. The upper crust value used by Martinez et al. (2010) has a low Ti/Al ratio compared to the platform and sediment trap data (Fig. S11) and such a low value indeed was mathematically needed in order to compute the $\mathrm{Ti} / \mathrm{Al}$ ratio of the sediment trap. From our observations, the low $\mathrm{Ti} / \mathrm{Al}$ ratios in the sediment traps and cores result from differential settling and not from the addition of an unknown additional detrital source. This implies that caution must be taken in quantitative 
provenance analysis using geochemical data: 1) Me/Al ratios are affected by the selective enrichment of clays and depletion of quartz and heavy minerals during transport; 2) using references such as PAAS, NASC or upper crust in computation is not always pertinent and may lead to erroneous interpretation of sources.

In most Me vs. Al plots, the sediment trap data present a lower slope than core data. A direct interpretation and comparison with platform data implies that the sediment traps are more influenced by the Tuy River (lowest Me/Al ratios) than the cores (Fig. S10). Similarly, when the ODP data are compared to theMD03 data, the latter generally present a lower slope than the former, suggesting that the MD03 core is more influenced by the Tuy River than the ODP core. Similarly, in the Th vs. Hf and Th vs. Rb plots, sediment traps present lower Th contents than cores and therefore tend to plot towards the Tuy River. These conclusions are opposite to what is expected from the location of the cores respectively to the river mouths (Fig. 1) as well as by the direction of currents in the Cariaco Basin. Only in the $\mathrm{Gd} / \mathrm{Yb}$ vs. $\mathrm{La} / \mathrm{Yb}$ plot direct interpretation of slopes indicates that the sediment trap data are more influenced by the Neveri + Manzanares rivers than the sediment cores.

\subsubsection{Other binary plots}

A way of avoiding problems due to differential settling during transport is to use chemical elements that are associated with grains of similar hydraulic behavior: Ti, Zr, Hf, Th and $(\mathrm{H}) \mathrm{REE}$ that are mostly associated with heavy minerals. Several plots were tested but, as illustrated on Figs. 7A and S12A, plotting Zr vs. Ti did not allow a better discrimination of sources compared to the Me vs. Al diagrams. An interesting discrimination was however obtained in the Hf vs. Th plot (Figs. 7B, S12B) since the Neveri River has an average Th/Hf ratio similar to that of the Tuy River. Direct interpretation of the temporal variations in the Th vs. Hf plot indicates that interglacials are dominated by the Tuy + Neveri rivers while glacials are more influenced by the Unare River. This plot also indicates that samples from MIS6 and the Ti-rich samples of MIS3 and 5 are influenced by the Unare North and/or Manzanares. In these plots, the coarser sediments from the 0-14.6 ka interval have a similar slope as the muddy sediments from MIS5 (Fig. 7A, B), indicating that the modest changes in sediment grain size have no influence on the temporal trend.

A binary plot of REE ratios was also tested. In this case, detrital sources are characterized by their specific ratios and therefore by geochemical fields. In the tested $\mathrm{La} / \mathrm{Yb}$ vs. Gd/Yb plot (Figs. 7C, S12C), the different sources are relatively discriminated, though there is some overlap between the Tuy River and Unare South area. Despite the relatively 
large error bars (Fig. 7), temporal fluctuations of core data appear significant and can be interpreted in terms of source. The overlap of 0-14.6 ka interval and MIS5 confirms that changes in grain size have no influence on the temporal trend. Compared to the platform, cores and sediment trap show generally higher values of $\mathrm{La} / \mathrm{Yb}$ and $\mathrm{Gd} / \mathrm{Yb}$ (Fig. S12C). This feature possibly results from mineral sorting as LREE are associated with clay minerals while HREE are associated with heavy minerals (see Section 5.1. and Mongelli, 1995). When shifting core data to slightly lower $\mathrm{La} / \mathrm{Yb}$ and $\mathrm{Gd} / \mathrm{Yb}$ values, in order to account for differential settling and compare with the platform, the temporal trend indicates that interglacial sediments (0-14.6 and MIS5) are mainly influenced by a mixture of Tuy + Unare rivers while sediments of MIS2-3 could plot directly on the Unare south field. Ti-rich samples of MIS3 are displaced towards the Unare North field and MIS6 samples plot in a mixture of Unare North + Manzanares. These interpretations are consistent with the pattern indicated by the clay minerals (Riboulleau et al., 2014). Unfortunately, the degree to which values must be shifted in order to account for mineral sorting during transport cannot be estimated with current data. As a result, quantitative estimation of the proportion of each source is not possible.

\subsubsection{Trace and rare earth ternary plots}

Several ternary plots were tested and the best discriminations of sources are obtained by using $\mathrm{Ti}-\mathrm{Zr}-\mathrm{Th}, \mathrm{Ti}-\mathrm{Zr}-\mathrm{La}$, and $\mathrm{Lu}-\mathrm{Hf}-\mathrm{Th}$ ternary plots (Fig. 8). Moreover, the sediment trap and core data generally plot between the different sources, consistent with a mixing of these sources. Differential settling probably affects the $\mathrm{Ti}-\mathrm{Zr}-\mathrm{La}$ diagram as sediment trap data, and to a lesser extent core data, are shifted towards the La pole compared to the platform data. Similar observation can be made in the Lu-Hf-Th diagram where sediment trap and core data are slightly shifted towards the Th pole. This is consistent with the fact that LREE and Th are mainly controlled by clay minerals. Direct interpretation of the temporal variations (Fig. 8) suggests that glacial samples have a strong influence from the Unare River while the present interglacial andMIS5 samples show a stronger influence from a mixture of Tuy+ Manzanares + Neveri rivers. The overlapping of the data from the 0-14.6 ka intervalwithMIS5 confirms that the temporal evolution is not affected by the slight variations in sediment grain size.

The $16.8 \mathrm{ka}$ sample and Ti-rich samples of MIS3 plot towards the Unare North (+Manzanares) field while Ti-rich samples ofMIS5 and 6, are shifted towards the Manzanares field. A variable geographic origin of the Ti-rich material is consistent with the different 
heavy mineral associations observed in the two studied samples (Section 4.3, Figs. S4-S7). Ti-rich samples generally were deposited during climatic oscillations (Heinrich events or cold stadials; Chapman and Shackleton, 1999; Hemming, 2004) associated with rapid sea level variations (Fig. 3; Siddall et al., 2003; Rohling et al., 2004). Remobilization of sediment deposited on the Unare platform during rapid sea level variations was suggested by the clay mineral content (Riboulleau et al., 2014). The geochemical data are consistent with this interpretation but indicate an additional contribution from the Manzanares area. This latter contribution could correspond to material eroded from the Gulf of Cariaco during the rapid sea level fluctuations, as several erosional unconformities were observed in the Gulf of Cariaco sediments (Fig. 3; Van Daele et al., 2011).

In the presented three ternary plots (Fig. 8), several samples of the most recent interval $(0-14.6 \mathrm{ka})$ are shifted towards the Manzanares and/or Unare North fields. These samples were similarly shifted in the $\mathrm{La} / \mathrm{Yb}$ vs. Gd/Yb cross plot (Fig. 7). Careful examination of the different metal cross plots (Figs. 6 and 7) reveals that these samples, deposited during the YD and Preboreal (PB), are often subtly shifted compared to other samples of the interglacial. Dry and windy conditions during the YD directly around the Cariaco Basin are well documented (Peterson et al., 1991; Lin et al., 1997; Haug et al., 2001; Hughen et al., 2004b; Makou et al., 2007). Following the YD, the PB was marked by a progressive evolution to warmer and more humid conditions that subsequently remained more or less stable through the Holocene (Haug et al., 2001; Hughen et al., 2004b; Makou et al., 2007). This YD-PB climatic oscillation is also documented by several palynological records from northern South America (van 't Veer et al., 2000; Rull et al., 2005, 2010; Montoya et al., 2011). The ternary plots and the La/Yb vs. $\mathrm{Gd} / \mathrm{Yb}$ plot suggest that the source of the detrital flux to the Cariaco Basin was slightly different during the climatic oscillation of the YD- PB compared to the Holocene, with increased contribution from the Manzanares and/or Unare North areas. A rapid sea-level rise is documented at the end of the YD and during the Preboreal, termed the "Meltwater Pulse 1B" (Fairbanks, 1989). This could have promoted the remobilization of sediment deposited on the Unare platform. Van Daele et al. (2011) indicate that connection between the Gulf of Cariaco and the Cariaco Basin likely established during the Meltwater Pulse 1B. This connection could have resulted in an episode of important influx of sediments originating from the Gulf of Cariaco and bearing a "Manzanares" geochemical signature into the Cariaco Basin. The clay-mineral content of the sediment, however, is not consistent with this interpretation and suggests that additional detrital source(s), possibly of eolian origin, contributed to the sedimentation in the Cariaco Basin during the YD-PB (Riboulleau et al., 
2014). Geochemical analyses of Saharan eolian particles deposited in Barbados (Muhs et al., 2007) allow exploring further this alternative. According to their grain size, Saharan eolian particles recovered at Barbados show a different geochemical signature (Muhs et al., 2007; Fig. S13). While the finest eolian particles cannot account for the shift observed in the YDPB samples from the Cariaco Basin, the largest ones (N10 $\mu \mathrm{m})$ overlap with the Unare North area, and plot close to the Unare South and Manzanares areas (Fig. S13) and therefore can account for the observed shift. As strong wind activity over the tropics likely favored the transport of the largest particles, the geochemical data support the contribution of Sahara eolian particles to the Cariaco Basin during the YD and PB (Riboulleau et al., 2014). Clay minerals suggested that MIS6-5 transition also showed a contribution of this eolian source and was marked by a YD-like event (Riboulleau et al., 2014). Because of the coarser-grained character (silt) of most samples fromMIS6, the geochemical data appears to be less precise than the clay-mineral assemblages. Nevertheless, from the location of samples in the ternary plots (Fig. 8), the geochemical data do not preclude a similar Saharan eolian contribution during the end of MIS6.

\section{Conclusion}

The very well-constrained sedimentary context of the Cariaco Basin offers an opportunity to test the validity of sediments bulk geochemistry as an indicator of detrital provenance. Several simple binary and ternary diagrams were used in order to test how the different detrital sources can be discriminated and how the temporal evolution of their contributions can be recognized.

- A-CN-K and MFW ternary diagrams based on major element contents did not allow a good discrimination of the different sources to the basin. In terms of provenance analysis, more consistent conclusions were reached with the $\mathrm{A}-\mathrm{CN}-\mathrm{K}$ diagram than with the MFW diagram. Mineral sorting during transport appears as a major drawback to the application of the A-CN$\mathrm{K}$ diagram to sediments.

- Metal vs. Al cross plots did not allow a clear discrimination of the different sources as several rivers yield similar Me/Al ratios. Temporal trends can be partly interpreted from the Me vs. Al diagrams, but erroneous conclusions can also be reached. Most metal cross plots based on immobile elements associated with heavy minerals did not give pertinent results.

- A relatively good discrimination of sources and a consistent interpretation of temporal variations were obtained using $\mathrm{Hf}$ vs. $\mathrm{Th}, \mathrm{La} / \mathrm{Yb}$ vs. $\mathrm{Gd} / \mathrm{Yb}$ and ternary diagrams combining immobile elements, or immobile elements and REE diagram. 
Despite the poor geochemical contrast of the different detrital sources to the Cariaco Basin, several simple geochemical diagrams allowed a pertinent provenance analysis. Moreover, this geochemical approach allowed to better identify the origin of detrital events: 1) redeposited sediments eroded from the Unare platform and Gulf of Cariaco during rapid sea level fluctuations and 2) Saharan eolian particles during the Younger Dryas-Preboreal and MIS6-5 transition.

The choice of elements to be plotted was determined after consideration of carrier minerals; different elements may therefore be informative in different sedimentary contexts. Overall a major limit to quantitative interpretation is mineral sorting during transport, which leads to selective enrichment in elements associated with clays, in particular Al and Rb, but also Th and LREE. For this reason, 1) using references such as PAAS, NASC or upper crust in computation is not pertinent and may lead to erroneous interpretation of sources; 2) even diagrams based on immobile elements do not allow quantitative estimation of the contribution of sources. Unless the geochemical effect of mineral sorting can be measured, quantitative provenance analysis should better be performed by comparing fractions of similar grain size and not bulk sediment.

\section{Acknowledgments}

We wish to thank the ODP program for providing sediment samples from core 1002 as well as the IMAGES program and crew of the R/V Marion Dufresne. Léa-Marie Bernard and Marion Delattre are acknowledged for the treatment and handling of sediment samples. Financial support for this study was provided by the project "Enfouissement organique dans le bassin de Cariaco: contrôles climatique et diagénétique" through the French national EVECYBER- LEFE program (INSU-CNRS). Michael E. Böttcher (editor), Georgia Pe-Piper, David J.W. Piper and an anonymous reviewer are acknowledged for their constructive comments which helped to significantly improve the paper.

\section{References}

Alfonso, P., Melgarejo, J.C., Yusta, I., Velasco, F., 2003. Geochemistry of feldspars and muscovite in granitic pegmatite from the Cap de Creus field, Catalonia, Spain. Can.Mineral. 41 (1), 103-116.

Armstrong-Altrin, J.S., Verma, S.P., 2005. Critical evaluation of six tectonic setting discrimination diagrams using geochemical data of Neogene sediments from known tectonic settings. Sediment. Geol. 177 (1-2), 115-129. 
Bhatia, M., Crook, K.W., 1986. Trace element characteristics of graywackes and tectonic setting discrimination of sedimentary basins. Contrib. Mineral. Petrol. 92 (2), 181-193.

Black, D.E., Hameed, S., Peterson, L.C., 2009. Long-term tidal cycle influences on a LateHolocene clay mineralogy record from the Cariaco Basin. Earth Planet. Sci. Lett. 279 (1-2), $139-146$.

Bout-Roumazeilles, V., Riboulleau, A., du Châtelet, E.A., Lorenzoni, L., Tribovillard, N., Murray, R.W., Müller-Karger, F., Astor, Y.M., 2013. Clay mineralogy of surface sediments as a tool for deciphering river contributions to the Cariaco Basin (Venezuela). J. Geophys. Res. Oceans 118 (2), 750-761.

Carignan, J., Hild, P., Mevelle, G., Morel, J., Yeghicheyan, D., 2001. Routine analyses of trace elements in geological samples using flow injection and low pressure on-line liquid chromatography coupled to ICP-MS: a study of geochemical reference materials BR, DR-N, UB-N, AN-G and GH. Geostand. Newslett. 25 (2-3), 187-198.

Chapman, M.R., Shackleton, N.J., 1999. Global ice-volume fluctuations, North Atlantic ice rafting events, and deep-ocean circulation changes between 130 and 70 ka. Geology 27 (9), $795-798$.

Clayton, T., Pearce, R.B., Peterson, L.C., 1999. Indirect climatic control of the clay mineral composition of Quaternary sediments from the Cariaco basin, northern Venezuela (ODP Site 1002). Mar. Geol. 161 (2-4), 191-206.

Cullers, R.L., 2002. Implications of elemental concentrations for provenance, redox conditions, and metamorphic studies of shales and limestones near Pueblo, CO, USA. Chem. Geol. 191 (4), 305-327.

De Miró Orell, M., 1974. Morfología submarina y sedimentos marinos recientes del margen continental del nororiente de Venezuela. Comisión Organizadora de la III Conferencia de las Naciones Unidas sobre Derecho del Mar, Caracas (230 pp.). Drenzek, N.J., 2007. The Temporal Dynamics of Terrestrial Organic Matter Transfer to the Oceans: Initial Assessment and Application. MIT/WHOI, (224 pp.).

Elmore, A.C., Thunell, R.C., Styles, R., Black, D., Murray, R.W., Martinez, N., Astor, Y., 2009. Quantifying the seasonal variations in fluvial and eolian sources of terrigenous material to Cariaco Basin, Venezuela. J. S. Am. Earth Sci. 27 (2-3), 197-210.

Eriksson, K.A., Taylor, S.R., Korsch, R.J., 1992. Geochemistry of 1.8-1.67 Ga mudstones and siltstones from the Mount Isa Inlier, Queensland Australia: provenance and tectonic implications. Geochim. Cosmochim. Acta 56 (3), 899-909. 
Fairbanks, R.G., 1989. A 17,000-year glacio-eustatic sea level record: influence of glacial melting rates on the Younger Dryas event and deep-ocean circulation. Nature 342, 637-642. Fedo, C.M., Nesbitt, W.H., Young, G.M., 1995. Unraveling the effects of potassium metasomatism in sedimentary rocks and paleosols, with implications for paleoweathering conditions and provenance. Geology 23 (10), 921-924.

Ferraz-Reyes, E., 1983. Estudio del fitoplancton en la cuenca Tuy-Cariaco, Venezuela. Bol. Inst. Oceanogr. Venez. Univ. Oriente 22 (1-2), 111-124.

Franz, G., Andrehs, G., Rhede, D., 1996. Crystal chemistry of monazite and xenotime from Saxothuringian-Moldanubian metapelites, NE Bavaria, Germany. Eur. J. Mineral. 8 (5), $1097-1118$.

Fujimaki, H., 1986. Partition coefficients of Hf, Zr, and REE between zircon, apatite, and liquid. Contrib. Mineral. Petrol. 94 (1), 42-45.

Garcia, D., Ravenne, C., Maréchal, B., Moutte, J., 2004. Geochemical variability induced by entrainment sorting: quantified signals for provenance analysis. Quant. Proven. Anal. Sediments $171(1-4), 113-128$.

Garver, J.I., Royce, P.R., Smick, T.A., 1996. Chromium and nickel in shale of the Taconic foreland; a case study for the provenance of fine-grained sediments with an ultramafic source. J. Sediment. Res. 66 (1), 100-106.

Gieré, R., Sorensen, S.S., 2004. Allanite and other REE-rich epidote-group minerals. Rev. Mineral. Geochem. 56 (1), 431-493.

Goldbrunner, A.W., 1984. Atlas climatológico de Venezuela 1951-1970. Servicio de Meteorología de la Fuerza Aérea Venezolana, Maracay, Venezuela, (68 pp.).

Goni, M.A., Aceves, H., Benitez-Nelson, B., Tappa, E., Thunell, R., Black, D.E., Muller Karger, F.,

Astor, Y., Varela, R., 2009. Oceanographic and climatologic controls on the compositions and fluxes of biogenic materials in the water column and sediments of the Cariaco Basin over the Late Holocene. Deep-Sea Res. I Oceanogr. Res. Pap. 56 (4), 614-640.

Green, T.H., Pearson, N.J., 1983. Effect of pressure on rare earth element partition coefficients in common magmas. Nature 305 (5933), 414-416.

Hackley, P.C., Urbani, F., Karlsen, A.W., Garrity, C.P. (2006) Mapa Geológico de Venezuela a Escala 1:750,000. U.S.G.S. Open file report 2006-1109. (online only), http://pubs.usgs. gov/of/2006/1109/. 
Haug, G.H., Hughen, K.A., Sigman, D.M., Peterson, L.C., Rohl, U., 2001. Southward migration of the intertropical convergence zone through the Holocene. Science 293 (5533), 1304-1308.

Hemming, S.R., 2004. Heinrich events: massive late Pleistocene detritus layers of the North Atlantic and their global climate imprint. Rev. Geophys. 42 (1), RG1005.

Hughen, K.A., Overpeck, J.T., Peterson, L.C., Trumbore, S., 1996. Rapid climate changes in the tropical Atlantic region during the last deglaciation. Nature 380 (6569), 51-54.

Hughen, K.A., Overpeck, J.T., Lehman, S.J., Kashgarian, M., Southon, J.R., 1998. A new $14 \mathrm{C}$ calibration data set for the last deglaciation based on marine varves. Radiocarbon 40 (1), 483-494.

Hughen, K.A., Southon, J.R., Lehman, S.J., Overpeck, J.T., 2000. Synchronous radiocarbon and climate shifts during the last deglaciation. Science 290 (5498), 1951-1954.

Hughen, K., Lehman, S., Southon, J., Overpeck, J., Marchal, O., Herring, C., Turnbull, J., 2004a. 14C activity and global carbon cycle changes over the past 50,000 years. Science 303 (5655), 202-207.

Hughen, K.A., Eglinton, T.I., Xu, L., Makou, M., 2004b. Abrupt tropical vegetation response to rapid climate changes. Science 304 (5679), 1955-1959.

Hughen, K., Southon, J., Lehman, S., Bertrand, C., Turnbull, J., 2006. Marine-derived 14C calibration and activity record for the past 50,000 years updated from the Cariaco Basin. Quat. Sci. Rev. 25 (23-24), 3216-3227.

Hutton, C.O., 1950. Studies of heavy detrital minerals. Geol. Soc. Am. Bull. 61 (7), 635-710. Joo, Y.J., Lee, Y.I., Bai, Z., 2005. Provenance of the Qingshuijian Formation (Late Carboniferous), NE China: implications for tectonic processes in the northern margin of the North China block. Sediment. Geol. 177 (1-2), 97-114.

Klemme, S., Prowatke, S., Hametner, K., Günther, D., 2005. Partitioning of trace elements between rutile and silicate melts: implications for subduction zones. Geochim. Cosmochim. Acta 69 (9), 2361-2371.

Laj, C., Shipboard Scientific Party, 2004. MD132/IMAGES XI, PICASSO cruise report. Latimer, J.C., Filippelli, G.M., Hendy, I.L., Gleason, J.D., Blum, J.D., 2006. Glacialinterglacial terrigenous provenance in the southeastern Atlantic Ocean: the importance of deepwater sources and surface currents. Geology 34 (7), 545-548.

Lin, H.L., Peterson, L.C., Overpeck, J.T., Trumbore, S.E., Murray, D.W., 1997. Late Quaternary climate change from delta O-18 records of multiple species of planktonic 
foraminifera: high-resolution records from the anoxic Cariaco Basin, Venezuela. Paleoceanography 12 (3), 415-427.

Lisiecki, L.E., Raymo, M.E., 2005. A Pliocene-Pleistocene stack of 57 globally distributed benthic $\delta 180$ records. Paleoceanography 20 (1), PA1003.

Mahlen, N.J., Johnson, C.M., Baumgartner, L.P., Beard, B.L., 2005. Provenance of Jurassic Tethyan sediments in the HP/UHP Zermatt-Saas ophiolite, western Alps. Geol. Soc. Am. Bull. 117 (3-4), 530-544.

Makou, M.C., Hughen, K.A., Xu, L., Sylva, S.P., Eglinton, T.I., 2007. Isotopic records of tropical vegetation and climate change from terrestrial vascular plant biomarkers preserved in Cariaco Basin sediments. Org. Geochem. 38 (10), 1680-1691.

Martinez, N.C., 2009. Sources of Terrigenous Material in the Modern Cariaco Basin and in the Cenozoic Arctic Ocean: Using Geochemical Provenance as a Proxy for Climatic and Paleoceanographic Change. Boston University, (PhD, 210 pp.).

Martinez, N.C., Murray, R.W., Thunell, R.C., Peterson, L.C., Muller-Karger, F., Astor, Y., Varela, R., 2007. Modern climate forcing of terrigenous deposition in the tropics (Cariaco Basin, Venezuela). Earth Planet. Sci. Lett. 264 (3-4), 438-451.

Martinez, N.C., Murray, R.W., Thunell, R.C., Peterson, L.C., Muller-Karger, F., Lorenzoni, L., Astor, Y., Varela, R., 2010. Local and regional geochemical signatures of surface sediments from the Cariaco Basin and Orinoco Delta, Venezuela. Geology 38 (2), 159-162.

McLennan, S.M., 1989. Rare earth elements in sedimentary rocks; influence of provenance and sedimentary processes. Rev. Mineral. Geochem. 21 (1), 169-200.

McLennan, S.M., 1993. Weathering and global denudation. J. Geol. 101 (2), 295-303.

McLennan, S.M., Hemming, S.R., McDaniel, D.K., Hanson, G.N., 1993. Geochemical approaches to sedimentation, provenance, and tectonics. In: Johnson, M.J., Basu, A. (Eds.), Processes Controlling the Composition of Clastic Sediments, pp. 21-40.

Meinhold, G., Kostopoulos, D., Reischmann, T., 2007. Geochemical constraints on the provenance and depositional setting of sedimentary rocks from the islands of Chios, Inousses and Psara, Aegean Sea, Greece: implications for the evolution of Palaeotethys. J. Geol. Soc. 164 (6), 1145-1163.

Michalopoulos, P., Aller, R.C., Reeder, R.J., 2000. Conversion of diatoms to clays during early diagenesis in tropical, continental shelf muds. Geology 28 (12), 1095-1098.

Mongelli, G., 1995. Trace elements distribution and mineralogical composition in the $b 2-\mu \mathrm{m}$ size fraction of shales from the Southern Apennines, Italy. Mineral. Petrol. 53 (1-3), 103114. 
Mongelli, G., Cullers, R.L., Muelheisen, S., 1996. Geochemistry of Late CretaceousOligocenic shales from the Varicolori Formation, Southern Apennines, Italy: implications for mineralogical, grain-size control and provenance. Eur. J. Mineral. 8 (4), 733-754.

Monien, D., Kuhn, G., von Eynatten, H., Talarico, F.M., 2012. Geochemical provenance analysis of fine-grained sediment revealing Late Miocene to recent Paleo- Environmental changes in the Western Ross Sea, Antarctica. Glob. Planet. Chang. 96-97, 41-58.

Montero-Serrano, J.C., Bout-Roumazeilles, V., Sionneau, T., Tribovillard, N., Bory, A., Flower, B.P., Riboulleau, A., Martinez, P., Billy, I., 2010. Changes in precipitation regimes over North America during the Holocene as recorded by mineralogy and geochemistry of Gulf of Mexico sediments. Glob. Planet. Chang. 74 (3-4), 132-143.

Montoya, E., Rull, V., Stansell, N.D., Bird, B.W., Nogué, S., Vegas-vilarrúbia, T., Abbott, M.B., Díaz, W.A., 2011. Vegetation changes in the Neotropical Gran Sabana (Venezuela) around the Younger Dryas chron. J. Quat. Sci. 26 (2), 207-218.

Muhs, D.R., Budahn, J.R., Prospero, J.M., Carey, S.N., 2007. Geochemical evidence for African dust inputs to soils of western Atlantic islands: Barbados, the Bahamas, and Florida.

J. Geophys. Res. Earth Surf. 112 (F2), F02009

Muller-Karger, F., Varela, R., Thunell, R., Astor, Y., Zhang, H., Luerssen, R., Hu, C., 2004. Processes of coastal upwelling and carbon flux in the Cariaco Basin. Deep-Sea Res. II Top. Stud. Oceanogr. 51 (10-11), 927-943.

Nesbitt, H.W., Young, G.M., 1982. Early Proterozoic climates and plate motions inferred from major element chemistry of lutites. Nature 299 (5885), 715-717.

Nesbitt, H., Young, G., 1984. Prediction of some weathering trends of plutonic and volcanic rocks based on thermodynamic and kinetic considerations. Geochim. Cosmochim. Acta 48 (7), 1523-1534.

Ohta, T., 2004. Geochemistry of Jurassic to earliest Cretaceous deposits in the Nagato Basin, SW Japan: implication of factor analysis to sorting effects and provenance signatures. Quant. Proven. Anal. Sediments 171 (1-4), 159-180.

Ohta, T., Arai, H., 2007. Statistical empirical index of chemical weathering in igneous rocks: a new tool for evaluating the degree of weathering. Chem. Geol. 240 (3-4), 280-297.

Paillard, D., Labeyrie, L., Yiou, P., 1996. Macintosh program performs time-series analysis. Eos 77, 379 .

Passchier, S., 2004. Variability in geochemical provenance and weathering history of sirius group strata, transantarctic mountains: implications for Antarctic glacial history. J. Sediment. Res. 74 (5), 607-619. 
Pe-Piper, G., Triantafyllidis, S., Piper, D.J.W., 2008. Geochemical identification of clastic sediment provenance from known sources of similar geology: the Cretaceous Scotian Basin, Canada. J. Sediment. Res. 78 (9), 595-607.

Peterson, L.C., Haug, G.H., 2006. Variability in the mean latitude of the Atlantic Intertropical Convergence Zone as recorded by riverine input of sediments to the Cariaco Basin (Venezuela). Palaeogeogr. Palaeoclimatol. Palaeoecol. 234 (1), 97-113.

Peterson, L.C., Overpeck, J.T., Kipp, N.G., Imbrie, J., 1991. A high-resolution late Quaternary upwelling record from the anoxic Cariaco Basin, Venezuela. Paleoceanography 6, 99-119.

Peterson, L.C., Haug, G.H., Murray, R.W., Yarincik, K.M., King, J.W., Bralower, T.J., Kameo, K., Rutherford, S.D., Pearce, R.B., 2000. Late Quaternary stratigraphy and sedimentation at ODP Site 1002, Cariaco Basin (Venezuela). In: Leckie, R.M., Sigurdsson, H., Acton, G.D., Draper, G. (Eds.), Proceedings of the ODP, Scientific Results, pp. 85-99.

Piper, D.Z., Dean, W.E., 2002. Trace-element deposition in the Cariaco Basin, Venezuela shelf, under sulfate-reducing conditions. A History of the Local Hydrography and Global Climate, $20 \mathrm{ka}$ to the Present. USGS Professional Paper 1670 (1670, 41 pp.).

Quijada, M., 2012. Diagenèse organique dans un bassin euxinique, le bassin de Cariaco depuis 130 ka. Lille1, (Ph. D. Thesis, 202 pp.).

Riboulleau, A., Bout-Roumazeilles, V., Tribovillard, N., 2014. Controls on detrital sedimentation in the Cariaco Basin during the last climatic cycle: insight from clay minerals.

Quat. Sci. Rev. 94, 62-73.

Rohling, E.J., Marsh, R., Wells, N.C., Siddall, M., Edwards, N.R., 2004. Similar meltwater contributions to glacial sea level changes from Antarctic and northern ice sheets. Nature 430 (7003), 1016-1021.

Roser, B.P., Korsch, R.J., 1986. Determination of tectonic setting of sandstone-mudstone suites using $\mathrm{SiO} 2$ content and $\mathrm{K} 2 \mathrm{O} / \mathrm{Na} 2 \mathrm{O}$ ratio. J. Geol. 94 (5), 635-650.

Rull, V., Abbott, M.B., Polissar, P.J., Wolfe, A.P., Bezada, M., Bradley, R.S., 2005. 15,000yr pollen record of vegetation change in the high altitude tropical Andes at Laguna Verde Alta, Venezuela. Quat. Res. 64 (3), 308-317.

Rull, V., Stansell, N.D., Montoya, E., Bezada, M., Abbott, M.B., 2010. Palynological signal of the Younger Dryas in the tropical Venezuelan Andes. Quat. Sci. Rev. 29 (23-24), $3045-3056$. 
Ryan, K.M., Williams, D.M., 2007. Testing the reliability of discrimination diagrams for determining the tectonic depositional environment of ancient sedimentary basins. Chem. Geol. 242 (1-2), 103-125.

Savoy, L.E., Stevenson, R.K., Mountjoy, E.W., 2000. Provenance of Upper Devonian-Lower Carboniferous miogeoclinal strata, Southeastern Canadian Cordillera: link between tectonics and sedimentation. J. Sediment. Res. 70 (1), 181-193.

Schock, H.H., 1979. Distribution of rare-earth and other trace elements in magnetites. Chem. Geol. 26 (1-2), 119-133.

Schwandt, C.S., Papike, J.J., Shearer, C.K., 1996. Trace element zoning in pelitic garnet of the Black Hills, South Dakota. Am. Mineral. 81 (9-10), 1195-1207.

Scranton, M.I., 1988. Temporal variations in the methane content of the Cariaco Trench. Deep Sea Res. Part A Oceanogr. Res. Pap. 35 (9), 1511-1523. Shipboard Scientific Party, 1997. Site 1002. In: Sigurdsson, H., Leckie, R.M., Acton, G.D., et al. (Eds.), Proceedings of the Ocean Drilling Program, initial reports, pp. 359-373.

Siddall, M., Rohling, E.J., Almogi-Labin, A., Hemleben, C., Meischner, D., Schmelzer, I., Smeed, D.A., 2003. Sea-level fluctuations during the last glacial cycle. Nature 423 (6942), $853-858$.

Spalletti, L.A., Queralt, I., Matheos, S.D., Colombo, F., Maggi, J., 2008. Sedimentary petrology and geochemistry of siliciclastic rocks from the upper Jurassic Tordillo Formation (Neuquén Basin, western Argentina): implications for provenance and tectonic setting. J. S. Am. Earth Sci. 25 (4), 440-463.

Thunell, R., Benitez-Nelson, C., Varela, R., Astor, Y., Muller-Karger, F., 2007. Particulate organic carbon fluxes along upwelling-dominated continental margins: rates and mechanisms. Glob. Biogeochem. Cycles 21, GB1022. http://dx.doi.org/10.1029/2006GB002793.

Totten, M.W., Hanan, M.A., Weaver, B.L., 2000. Beyond whole-rock geochemistry of shales: the importance of assessing mineralogic controls for revealing tectonic discriminants of multiple sediment sources for the Ouachita Mountain flysch deposits. Geol. Soc. Am. Bull. 112 (7), 1012-1022.

Tribovillard, N., Algeo, T.J., Lyons, T., Riboulleau, A., 2006. Trace metals as paleoredox and paleoproductivity proxies: an update. Chem. Geol. 232 (1-2), 12-32.

Tribuzio, R., Messiga, B., Vannucci, R., Bottazzi, P., 1996. Rare earth element redistribution during high-pressure-low-temperature metamorphism in ophiolitic Fe-gabbros (Liguria, northwestern Italy): implications for light REE mobility in subduction zones. Geology 24 (8), $711-714$. 
Tuttle, J.H., Jannasch, H.W., 1979. Microbial dark assimilation of CO2 in the Cariaco Trench. Limnol. Oceanogr. 24 (4), 746-753.

van 't Veer, R., Islebe, G.A., Hooghiemstra, H., 2000. Climatic change during the Younger Dryas chron in northern South America: a test of the evidence. Quat. Sci. Rev. 19 (17-18), $1821-1835$.

Van Daele, M., van Welden, A., Moernaut, J., Beck, C., Audemard, F., Sanchez, J., Jouanne, F., Carrillo, E., Malavé, G., Lemus, A., et al., 2011. Reconstruction of Late-Quaternary sea and lake-level changes in a tectonically active marginal basin using seismic stratigraphy: the Gulf of Cariaco, NE Venezuela. Mar. Geol. 279 (1-4), 37-51.

Wakeham, S.G., Ertel, J.R., 1988. Diagenesis of organic matter in suspended particles and sediments in the Cariaco Trench. Org. Geochem. 13 (4-6), 815-822.

Wang, Y.J., Cheng, H., Edwards, R.L., An, Z.S., Wu, J.Y., Shen, C.C., Dorale, J.A., 2001. A high resolution absolute-dated late Pleistocene monsoon record from Hulu Cave, China. Science 294 (5550), 2345-2348.

Weltje, G.J., von Eynatten, H., 2004. Quantitative provenance analysis of sediments: review and outlook. Quant. Proven. Anal. Sediments 171 (1-4), 1-11.

Yang, S.Y., Jung, H.S., Lim, D.I., Li, C.X., 2003. A review on the provenance discrimination of sediments in the Yellow Sea. Earth Sci. Rev. 63 (1-2), 93-120.

Yarincik, K.M., Murray, R.W., Peterson, L.C., 2000. Climatically sensitive eolian and hemipelagic deposition in the Cariaco Basin, Venezuela, over the past 578,000 years: results from Al/Ti and K/Al. Paleoceanography 15 (2), 210-228.

Young, G.M., 1999. Some aspects of the geochemistry, provenance and palaeoclimatology of the Torridonian of NW Scotland. J. Geol. Soc. 156 (6), 1097-1111.

Young, G.M., Nesbitt, W.H., 1999. Paleoclimatology and provenance of the glaciogenic Gowganda Formation (Paleoproterozoic), Ontario, Canada: a chemostratigraphic approach. Geol. Soc. Am. Bull. 111 (2), 264-274. 


\section{Figure captions}



Fig. 1. Location map of the Cariaco Basin, of the studied core sections, as well as of the different samplings mentioned in the text: sediment trap (Thunell et al., 2007; Martinez, 2009), core PL07-39PC (Piper and Dean, 2002), and the different areas of the platform surrounding the basin (Martinez et al., 2010). MIS: marine isotopic stage. 


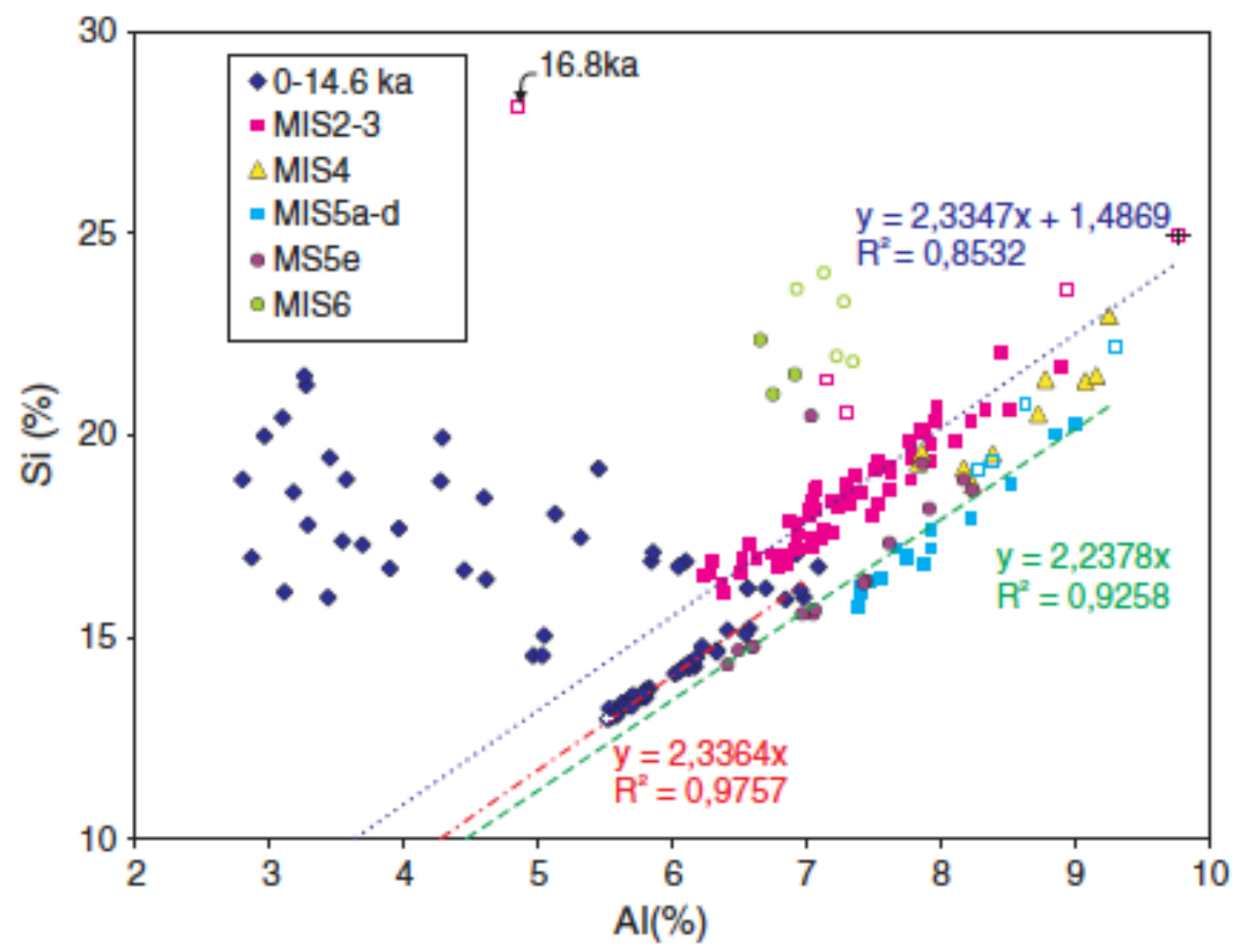

Fig. 2. Bivariate diagram of the silicium and aluminium contents in the sediments of cores MD03-2625 and ODP 1002 for different time intervals. Open symbols correspond to Ti-rich samples. Correlation lines are drawn for quartz-lean and opal-lean samples. Red dotted line: MIS2-3; blue dash-dotted line: 0-14.6 ka; green dashed line: MIS5a-toe. Error bars corresponding to the analytical uncertainty are shown for the samples having the lowest $\mathrm{Si}$ content and highest $\mathrm{Al}$ content. 


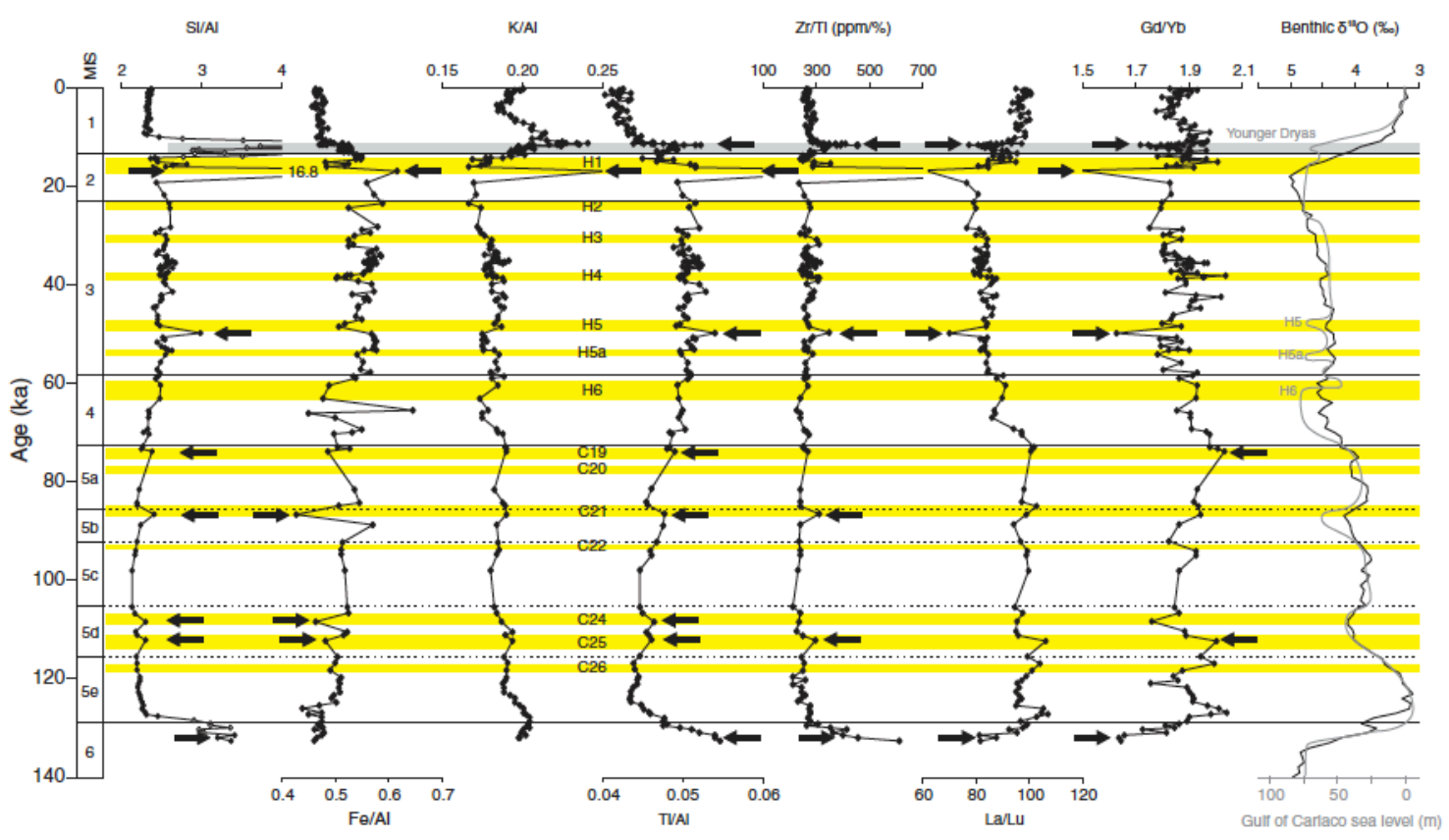

Fig. 3. Temporal variations of major, trace and rare earth element ratios compared to the global variations of the $\delta 180$ content of benthic foraminifera (Lisiecki and Raymo, 2005; black curve) and of the sea level variations in the Gulf of Cariaco (modified after Van Daele et al., 2011; gray curve). White diamonds in the $\mathrm{Si} / \mathrm{Al}$ figure indicate diatom-containing samples. Yellow horizontal bands indicate Heinrich events and cold stadials (Chapman and Shackleton, 1999; Hemming, 2004). Black arrows indicate Ti-rich samples (see text). 


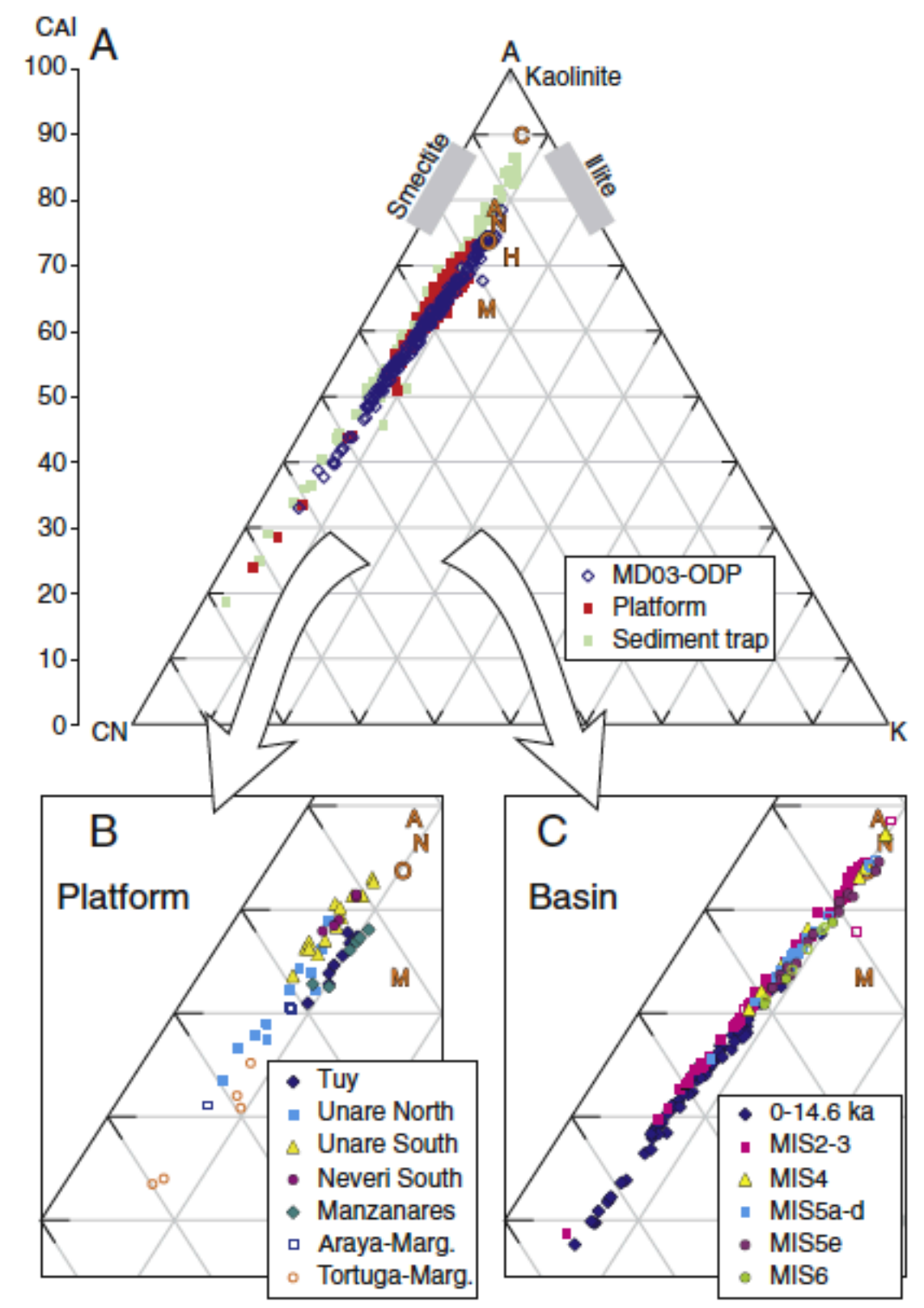

Fig. 4. Al2O3- $(\mathrm{CaO} *+\mathrm{Na} 2 \mathrm{O})-\mathrm{K} 2 \mathrm{O}(\mathrm{A}-\mathrm{CN}-\mathrm{K})$ ternary plot of samples from the Cariaco Basin. A: general distribution of the core samples (MD03-2625 and ODP 1002) in the diagram compared to sediment traps (Martinez, 2009) and platform sediments (Martinez et al., 2010). B: detailed distribution of platform sediments according to their location. C: detailed distribution of core samples according to their age. Open symbols correspond to Tirich samples. Suspended sediments from different rivers (McLennan, 1993) are also shown (orange letters) M: Mississippi River, H: Huanghe River, C: Congo River, A: Amazon River, O: Orinoco River, N: Nile River. 


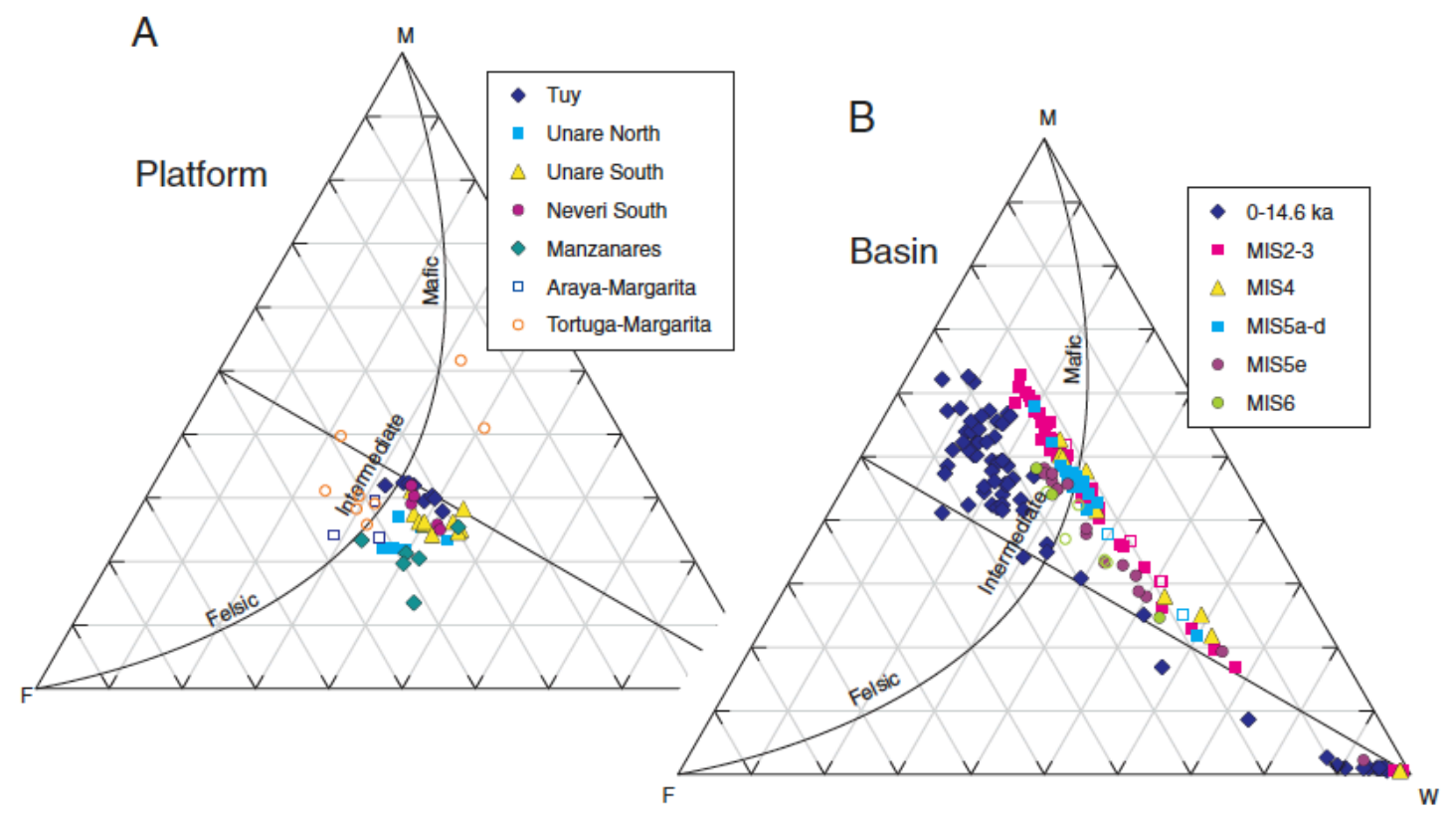

Fig. 5. MFW ternary plot of samples from the Cariaco Basin. A: distribution of platform sediments (Martinez et al., 2010) in the diagram according to their location. B: distribution of core samples (MD03-2625 and ODP 1002) according to their age. Open symbols correspond to Ti-rich samples. 

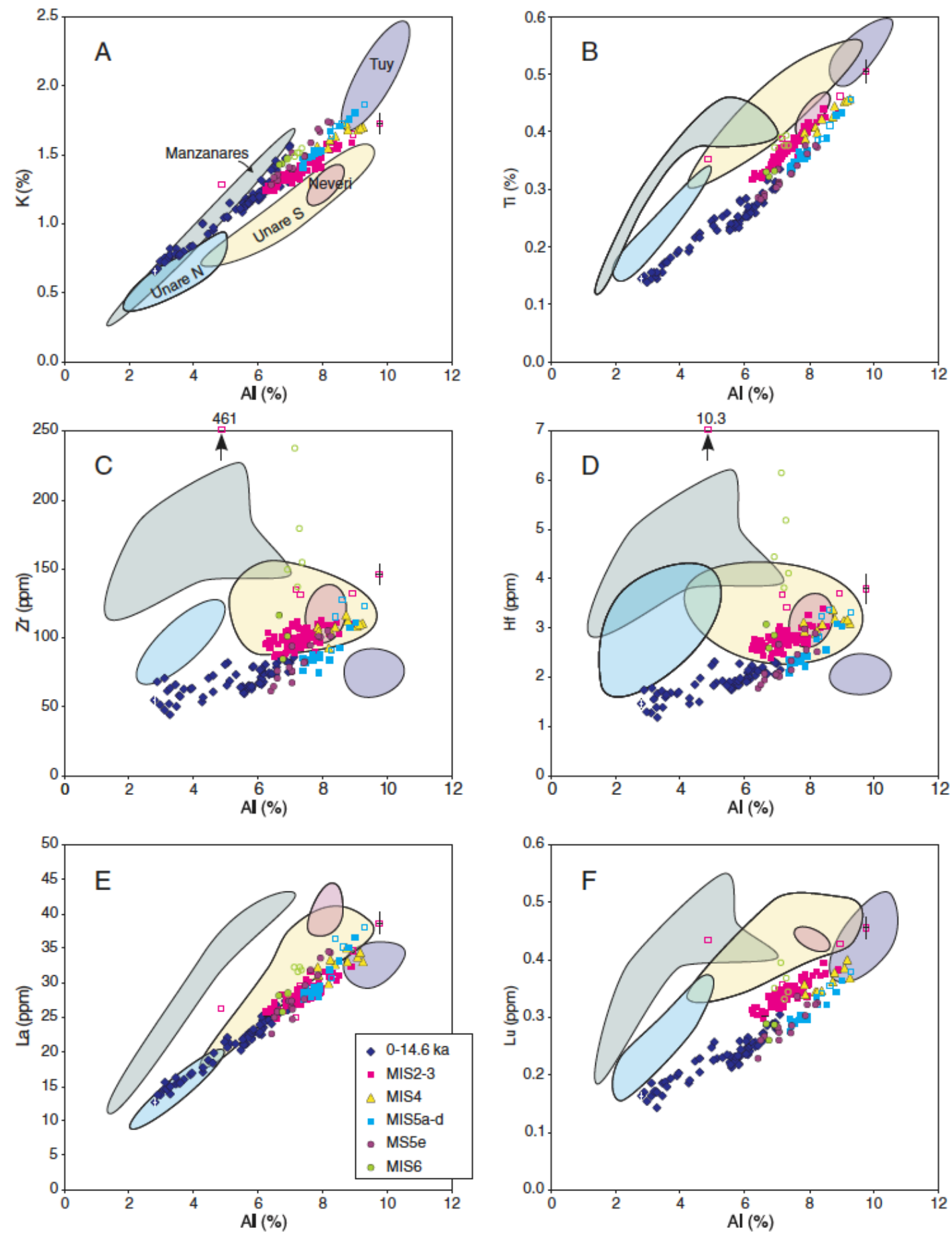

Fig. 6. Bivariate diagrams of differentmajor and immobile trace element contents in the core samples (MD03-2625 and ODP 1002) according to their age, compared to the field areas of the main detrital sources on the platform (data from Martinez et al., 2010; Fig. S2). Open symbols correspond to Ti-rich samples. Error bars corresponding to the analytical uncertainty are shown for the samples having the lowest and highest $\mathrm{Al}$ contents. 

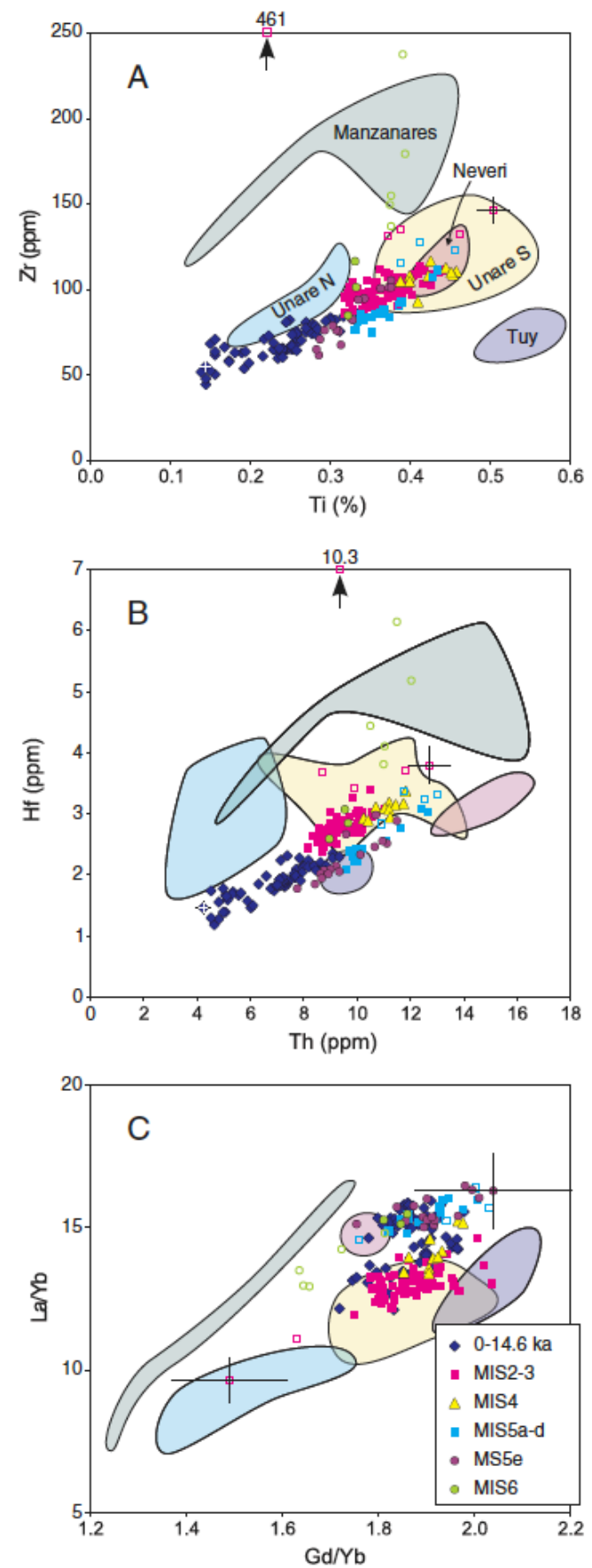

Fig. 7. Bivariate diagrams of selected immobile element contents and rare earth abundance ratios in the core samples (MD03-2625 and ODP 1002) according to their age, compared to the field areas of the main detrital sources on the platform (data from Martinez et al., 2010; Fig. S5). Open symbols correspond to Ti-rich samples. Error bars corresponding to the analytical uncertainty are shown for the samples having the lowest and highest Al contents except in $\mathrm{La} / \mathrm{Yb}$ vs $\mathrm{Gd} / \mathrm{Yb}$. 

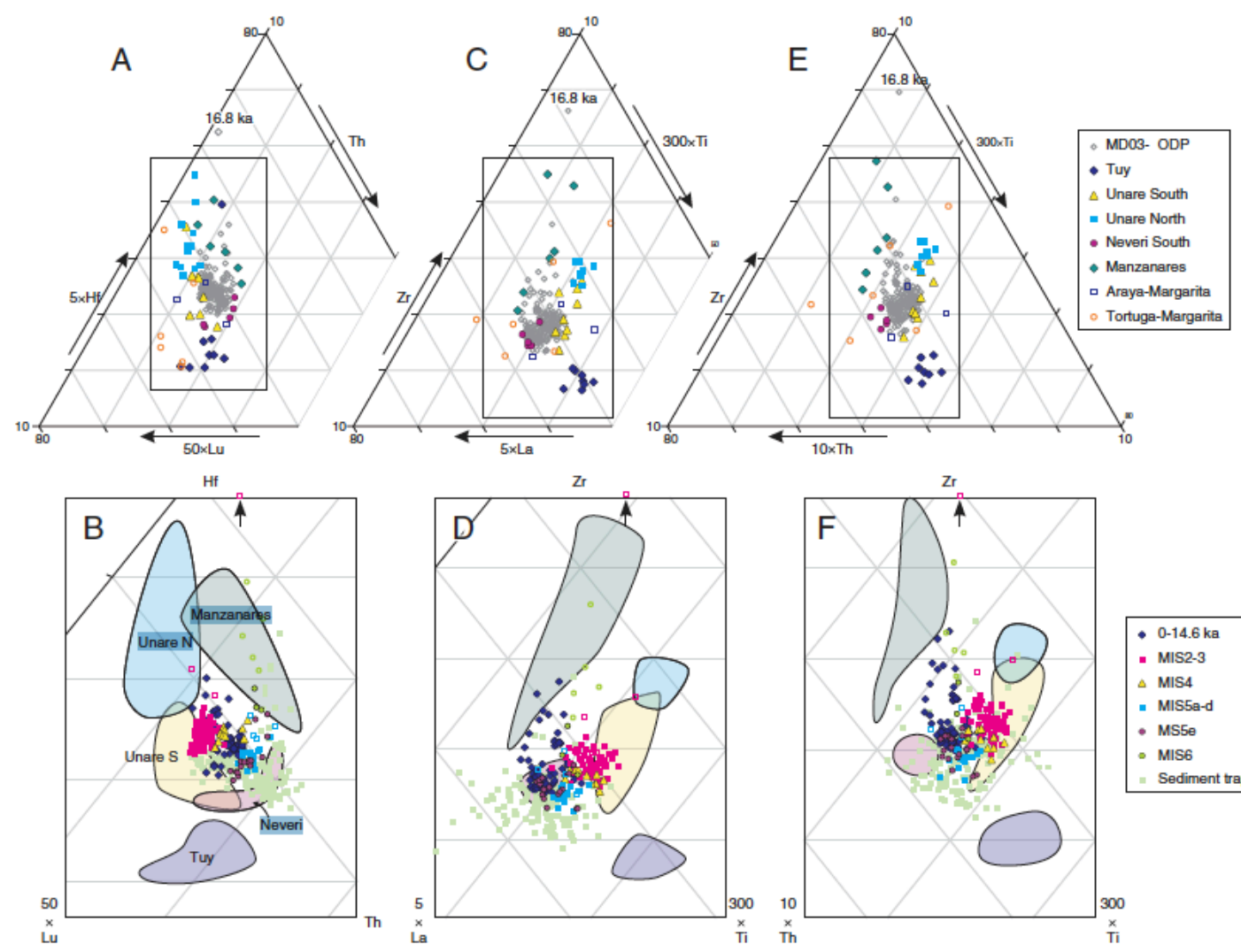

Fig. 8. Ternary plots of immobile element contents in the sediments of the Cariaco Basin. A, B: Lu-Hf-Th; C, D: La-Zr-Ti; E, F: Th-Zr-Ti. A, C, E: general viewshowing the distribution of data for the different source areas identified by Martinez et al. (2010) compared to core data (MD03-2625 andODP 1002). Rectangles indicate the location of the detailed views. B, D, F: detailed view showing the evolution of core data according to the age of the sediment, compared to the source areas and sediment trap data (Martinez, 2009). 
Table 1

Correlation coefficients between major and minor elements in sediments of the Cariaco Basin (cores MD03-2625 and ODP 1002).

\begin{tabular}{|c|c|c|c|c|c|c|c|}
\hline & $\mathrm{Al}(\mathscr{X})$ & $\mathrm{Fe}(\mathscr{x})$ & $\mathrm{Mg}$ (ஜ) & $\mathrm{Ca}(\mathrm{X})$ & $\mathrm{Na}(\mathscr{Z})$ & $\mathrm{K}(\%)$ & $\mathrm{Ti}(\mathscr{6})$ \\
\hline Si (જ) & 0.348 & 0.392 & 0.107 & -0.823 & -0.392 & 0.363 & 0.542 \\
\hline $\mathrm{Al}(\mathscr{x})$ & 1.000 & 0.943 & 0.398 & -0.679 & -0.804 & 0.968 & 0.953 \\
\hline $\mathrm{Fe}(\not)$ & & 1.000 & 0.447 & -0.722 & -0.804 & 0.869 & 0.958 \\
\hline $\mathrm{Mg}(\not)$ & & & 1.000 & -0.183 & -0.490 & 0.312 & 0.449 \\
\hline $\mathrm{Ca}(\%)$ & & & & 1.000 & 0.474 & -0.663 & -0.783 \\
\hline $\mathrm{Na}(\%)$ & & & & & 1.000 & -0.787 & -0.847 \\
\hline $\mathrm{K}(\%)$ & & & & & & 1.000 & 0.907 \\
\hline
\end{tabular}

Bold values indicate a correlation coefficient $>0.9$.

\section{Table 2}

Correlation coefficients $(\mathrm{n}=190)$ between Al-normalized detrital elements in core sediments of the Cariaco Basin and global seawater $\delta 180$ (Lisiecki and Raymo, 2005).

\begin{tabular}{lllll}
\hline $\mathrm{Si} / \mathrm{Al}$ & $\mathrm{Si} / \mathrm{Al}^{\mathrm{a}}$ & $\mathrm{Fe} / \mathrm{Al}$ & $\mathrm{K} / \mathrm{Al}$ & $\mathrm{Ti} / \mathrm{Al}$ \\
\hline-0.022 & 0.664 & 0.747 & -0.477 & 0.796 \\
\hline
\end{tabular}

a Without quartz-rich and opal-rich samples, $n=149$. 
Table 3

Values of the CIA for the different platform areas (Fig. 1), sediment traps, and different time intervals of cores MD03-2625 and ODP1002.

\begin{tabular}{llccc}
\hline & Average & Min & Max & sd \\
\hline Platform Martinez et al. (2010) & & & & \\
Tuy & 64.9 & 61.0 & 67.7 & 2.4 \\
Unare North & 60.9 & 53.5 & 68.8 & 4.4 \\
Unare South & 68.7 & 63.5 & 73.0 & 2.9 \\
Neveri South & 69.5 & 67.9 & 71.4 & 1.6 \\
Manzanares & 65.5 & 62.5 & 68.0 & 2.4 \\
Araya-Marg & 57.3 & 51.1 & 60.5 & 5.3 \\
Tortuga-Margarita & 41.5 & 24.0 & 55.2 & 11.6 \\
Sediment trap Martinez (2009) & 66.2 & 18.5 & 86.5 & 15.4 \\
& & & & \\
Cores (this study) & & & & \\
0-14.6 & 52.5 & 33.1 & 67.6 & 7.0 \\
MIS2-3 & 63.9 & 38.8 & 78.5 & 7.7 \\
MIS4 & 69.2 & 60.3 & 77.3 & 6.7 \\
MIS5a-d & 66.4 & 55.7 & 74.8 & 4.5 \\
MIS5e & 67.5 & 62.4 & 74.5 & 4.1 \\
MIS6 & 65.1 & 60.8 & 68.8 & 3.1 \\
\hline
\end{tabular}

Table 4

Grain size analysis of the sediment from cores MD03-2625 and ODP 1002 (Riboulleau et al., 2014).

\begin{tabular}{|c|c|c|c|c|c|c|}
\hline & $\begin{array}{l}\text { Mean grain } \\
\text { size }(\mu \mathrm{m})\end{array}$ & Clays (\%) & $\begin{array}{l}\text { Cohesive } \\
\text { silts }^{2}(\%)\end{array}$ & $\begin{array}{l}\text { Sortable } \\
\text { silts }^{b}(\%)\end{array}$ & $\begin{array}{l}\text { Total } \\
\text { silts ( } 8)\end{array}$ & Sand $(\mathscr{X})$ \\
\hline $0-14.6 \mathrm{ka}$ & 14.4 & 1 & 39 & 50 & 89 & 11 \\
\hline MIS2 & 8.3 & 3 & 57 & 38 & 96 & 1 \\
\hline MIS3 & 10.6 & 2 & 49 & 45 & 94 & 4 \\
\hline MIS4 & 7.5 & 3 & 62 & 33 & 95 & 2 \\
\hline MIS5a-d & 9.3 & 2 & 54 & 42 & 96 & 2 \\
\hline MIS5e & 8.9 & 2 & 55 & 42 & 96 & 1 \\
\hline MIS6 & 10.8 & 1 & 48 & 49 & 97 & 2 \\
\hline
\end{tabular}

